Review Article

\title{
Bioremediation of Chromium by Microorganisms and Its Mechanisms Related to Functional Groups
}

\author{
Abate Ayele $\mathbb{B}^{1}$ and Yakob Godebo Godeto $\mathbb{i D}^{2}$ \\ ${ }^{1}$ Department of Biotechnology, College of Biological and Chemical Engineering, Addis Ababa Science and Technology University, \\ Addis Ababa, Ethiopia \\ ${ }^{2}$ Department of Industrial Chemistry (Nanotechnology Centre of Excellence), College of Applied Sciences, \\ Addis Ababa Science and Technology University, Addis Ababa, Ethiopia \\ Correspondence should be addressed to Abate Ayele; abateayele.12@gmail.com
}

Received 2 June 2021; Revised 21 June 2021; Accepted 22 June 2021; Published 1 July 2021

Academic Editor: Yifeng Zhang

Copyright (C) 2021 Abate Ayele and Yakob Godebo Godeto. This is an open access article distributed under the Creative Commons Attribution License, which permits unrestricted use, distribution, and reproduction in any medium, provided the original work is properly cited.

\begin{abstract}
Heavy metals generated mainly through many anthropogenic processes, and some natural processes have been a great environmental challenge and continued to be the concern of many researchers and environmental scientists. This is mainly due to their highest toxicity even at a minimum concentration as they are nonbiodegradable and can persist in the aquatic and terrestrial environments for long periods. Chromium ions, especially hexavalent ions $(\mathrm{Cr}(\mathrm{VI}))$ generated through the different industrial process such as tanneries, metallurgical, petroleum, refractory, oil well drilling, electroplating, mining, textile, pulp and paper industries, are among toxic heavy metal ions, which pose toxic effects to human, plants, microorganisms, and aquatic lives. This review work is aimed at biosorption of hexavalent chromium $(\mathrm{Cr}(\mathrm{VI}))$ through microbial biomass, mainly bacteria, fungi, and microalgae, factors influencing the biosorption of chromium by microorganisms and the mechanism involved in the remediation process and the functional groups participated in the uptake of toxic $\mathrm{Cr}(\mathrm{VI})$ from contaminated environments by biosorbents. The biosorption process is relatively more advantageous over conventional remediation technique as it is rapid, economical, requires minimal preparatory steps, efficient, needs no toxic chemicals, and allows regeneration of biosorbent at the end of the process. Also, the presence of multiple functional groups in microbial cell surfaces and more active binding sites allow easy uptake and binding of a greater number of toxic heavy metal ions from polluted samples. This could be useful in creating new insights into the development and advancement of future technologies for future research on the bioremediation of toxic heavy metals at the industrial scale.
\end{abstract}

\section{Introduction}

The leakage of serious heavy metals from human and industrial activities into wastewater has become a major environmental issue. Water pollution is a major threat to human, land, and aquatic animals and plants, and it is attracting the attention of many researchers and scientists. The main reason for this may be traced back to the increase in different industrial activities which takes great part in producing plenty of waste and untreated water throughout the world. It has been emphasized that the water pollution induced from the large amounts of industrial effluents without proper treatment before disposing to the water bodies is causing a serious threat to the entire human health
[1], for example, water contaminated with atorvastatin (a drug used as cardiovascular ailments) has been causing adverse health effects such as myopathy, rhabdomyolysis, memory loss, forgetfulness and confusion, liver and muscle problems, diabetes, cognitive loss, neuropathy, pancreatic, and hepatic and sexual dysfunctions [2]. Various industrial, agricultural and domestic wastes dumped to water bodies can seriously pollute, and the potential contaminants can cause different diseases such as diarrheal diseases, vector borne diseases, cutaneous diseases, blindness, paralysis, and liver diseases (Chowdhary et al.). In general, organic dyes from textile and painting industries [1,3], different drugs from pharmaceuticals [2], inorganic pollutants and polysaccharides from distillery industries [4], smoke and organic 
wastes from pulp and paper industries [5], and wide varieties of heavy metals produced from metallurgical and electroplating, chemical, refractory brick, tanneries, wood preservation, pigments and dyes, textiles, etc., [6] are getting great environmental challenge and threatening the health of humans. Hence, great emphasis has been given by many researchers to heavy metals as they are highly toxic even at very lower concentration and continuously discharged to water bodies due to growing industrial activities.

Typically, heavy metals are those metallic elements and some metalloids with density higher than $5 \mathrm{gcm}^{-3}$ [7]. Chromium (Cr), cobalt $(\mathrm{Co})$, cupper $(\mathrm{Cu})$, cadmium $(\mathrm{Cd})$, arsenic (As), gallium $(\mathrm{Ga})$, germanium $(\mathrm{Ge})$, iron $(\mathrm{Fe})$, mercury $(\mathrm{Hg})$, lead $(\mathrm{Pb})$, nickel $(\mathrm{Ni})$, thallium $(\mathrm{Tl})$, selenium $(\mathrm{Se})$, and manganese $(\mathrm{Mn})$ are some commonly known heavy metals [8]. They cover most transitional metals, basic metals, some metalloids, lanthanides, and actinides, having high molecular weight, atomic number, and specific gravity. Various industrial sectors such as electroplating, tanneries, pulp and paper, textile, metallurgies, mining sectors, and dying and painting industries extensively consume different heavy metals for diverse purposes [9-11]. These and other heavy metals are being continuously discharged from the manufacturing industry into living environments, especially water bodies at concentrations in excess of the limits set by regulatory agencies. Heavy metal exposure has been one of the big global concerns due to its high toxicity, high bioaccumulation in the human body and food chain, the essence of nonbiodegradability, and most likely human carcinogenicity [12].

Heavy metals are reported to pose toxic effect in humans (causing different cardiovascular, inflammatory, and respiratory diseases) and other animals $[8,13]$; plants (disturb photosynthesis, production, and slow the growth) [14]; microorganisms (affect morphology, metabolism, and growth) [15]; and aquatic lives (affect reproduction and even death) [8]. Among toxic heavy metals, chromium is ranked among the top sixteen toxic contaminants that have adverse effects on human health as an essential metal [16]. Chromium is being used in various manufacturing sectors, such as the metallurgical, steel, tannery and cement industries, textiles, dying industries, which are major sources of pollution. Chromium can exist in various oxidation states among which, hexavalent $\mathrm{Cr}(\mathrm{VI})$ and trivalent $\mathrm{Cr}(\mathrm{III})$ states are most stable one and are most commonly discharged in to water bodies from industrial activities $[17,18]$. The hexavalent form is especially one of the most significant sources of environmental contamination and is documented for its nephrotoxic malignant neoplastic disease and is well known for its toxic, carcinogenic, and mutagenic effects on humans and other living organisms $[19,20]$.

Various water treatment technologies have been reported for the removal of toxic substances from the water bodies. Some of which include biofiltration, membrane filtration, biological activated carbon, advanced oxidation process, ion-exchange resins, and iminodiacetic acid-carbon nanotubes [21-23]. To date, adsorption technologies such as covalent organic frameworks- (COFs-) based materials [24], metal organic framework (MOF) [25], porous geopolymers
[26], biochar [27], chitosan-based adsorbents [28], 3D porous aerogels [29], agricultural and industrial wastes [30], nanomaterials [31], and biosorption [32] have been studied to remove toxic heavy metal contaminants from wastewater. More recently, efficient removal of $\mathrm{Cr}(\mathrm{VI})$ from the contaminated solutions has been reported. To mention, Zhu et al., [33] reported efficient removal of $\mathrm{Cr}(\mathrm{VI})$ using magnetite immobilized with Lysinibacillus sp. (a Grampositive, mesophilic, rod-shaped bacterium commonly found in soil) and studied the mechanisms and performance to be applied in large scale. On other hand, magnetic chitosan modified with graphene oxide nanocomposite has been employed for the removal of $\mathrm{Cr}(\mathrm{VI})$ from waste water where the synthesized adsorbents exhibited varied removal efficiency at solution $\mathrm{pH}$ of 2 [34].

The simple, inexpensive, and ecofriendly solution that can be performed over a wide range of experimental conditions for the detoxification and elimination of Cr-pollutants is bioremediation, which uses indigenous microorganisms [32]. Most bioremediation technologies such as biosorption produce less or no secondary wastes during removing toxic heavy metal ions [35] as secondary wastes may require further technologies to be managed. The processes by which microorganisms deal with toxic metals are biosorption, bioaccumulation, and enzymatic oxidation/ reduction [36]. Among bioremediation techniques, biosorption process using microbial biomass is reported to be simple, fast, economical, efficient, and also effective at industrial scales. Hence, this review work is focused on hexavalent chromium removal by biosorption using microorganisms, the mechanism involved in the removal process and the functional groups participating in the uptake of hexavalent chromium ions. In addition, an emphasis has also been given to some factors that affect haste, efficiency, and effectivities of biosorption process. In general, wide varieties of toxic heavy metals are continuously discharged into water bodies due to growing industrial and agricultural activities, and different emerging treatment technologies have been adopted to overcome such problems.

\section{Overview of Heavy Metals}

2.1. Industrial Heavy Metals as Major Water Pollutant. Most commonly, wastes can be discharged into the aquatic environment as domestic, agricultural, industrial, and radioactive wastes. Among these, industrial operation accounts for the largest portion of either emission of gases and discharge of different effluents. One of the main sources of water contamination is industrial wastewater, which contains high levels of heavy metals and other permanent hazardous substances. The rapid development of science and technology has taken the sector to a new stage of growth [37]. The key reasons for high pollution problems in the waste disposal field of the industry are waste toxicity and postdisposal behavior, inadequate treatment procedures, insufficient disposal, bad planning, and management of disposal sites. Wide varieties of heavy metals have been continuously discharged from industrial processes into water systems (both surface and underground waters) in 
different ways (as shown in Figure 1). Most commonly, Cr, $\mathrm{Hg}, \mathrm{Cd}$, and $\mathrm{Pb}$ from tanneries [9]; $\mathrm{Cu}, \mathrm{Pb}, \mathrm{Zn}, \mathrm{Hg}$, etc., from mining [40], $\mathrm{Hg}, \mathrm{Pb}, \mathrm{Cd}, \mathrm{Zn}, \mathrm{Cu}, \mathrm{Cr}, \mathrm{As}$, and $\mathrm{Ni}$ from coal production [11]; $\mathrm{Cd}, \mathrm{Cr}, \mathrm{Cu}, \mathrm{Fe}, \mathrm{Mn}, \mathrm{Ni}$, etc., from textile manufacturing [39]; $\mathrm{Fe}, \mathrm{Zn}, \mathrm{Cu}, \mathrm{Cr}, \mathrm{Cd}, \mathrm{Mn}, \mathrm{Ni}$, and $\mathrm{Pb}$ from pulp and paper [38], and others such as metal refining, electroplating, petroleum production, fertilizer, pesticide, and painting industries [10] also generate heavy metals which are discharged into environment with concentration higher than the proclaimed level by regulatory organizations.

Amidst various manufacturing industries, the tanning industry is an important contributor to the economy and, in particular, provides large-scale job opportunities to unskilled and/or trained individuals. Despite the great role of the leather industries in the social and economic development of the world, it is also the leading contributor of water contamination by heavy metals, mainly chromium. Wastewater from tanneries is primarily characterized by high levels of chemical demand for oxygen (COD), biochemical oxygen demand (BOD), turbidity, suspended solids (SS), sulfides, and chromium [41]. Huge quantities of heavy metals have been released worldwide into rivers or freshwater due to rapid global population growth, the expansion of global industrial and domestic activities, and agricultural development [42]. Heavy metals released into water bodies by waste have an incorrigible effect on the aquatic environment and damage the ability of an aquatic body to self-purify $[43,44]$.

Among several heavy metals generated from different industrial activities, the toxicity and health effects of chromium $(\mathrm{Cr})$, which is the dominant heavy metal from tanneries, attracted the attention of researchers. Chrome tanning is one of the leather tanning industry's most commonly used methods since it provides a product with the highest value at a fair price. As a result, this process accounts for about $8 \%$ of the weight of the leather as chromium salt is applied [45]. Although the tanning process is highly important in improving the quality and acceptability of leather products, it comprises several chemical compounds such as acids, vegetable tannin, mineral salts, such as chromium sulfate, and fish or animal oil, some of which are reported to be potentially toxic to human, plants, and aquatic lives $[43,46-48]$. Generally, industrial activity takes higher part in producing toxic heavy metals as waste, which directly or indirectly enter into water bodies, and $\mathrm{Cr}(\mathrm{VI})$ highly produced from tanneries is getting great challenges to be easily removed from water bodies.

\subsection{Definition, Sources, Speciation, and Properties of Chromium}

2.2.1. Definition and Properties of Chromium. Chromium is a steely-grey, lustrous, hard and brittle transitional metal symbolized $\mathrm{Cr}$, having atomic number 24 , molecular weight $51.9961 \mathrm{gmol}^{-1}$ and density $7.19 \mathrm{~g} / \mathrm{cm}^{3}$ at 20 , melting and boiling points at 1,907 and 2,672, respectively. In the modern periodic table, $\mathrm{Cr}$ is the first element of group 6 and corresponds to period 4 , a d-block element with an electronic configuration of $[\mathrm{Ar}] 3 \mathrm{~d}^{5} 4 \mathrm{~s}^{1}$ and is located between vanadium and manganese. Naturally occurring chromium is composed of three stable isotopes: ${ }^{52} \mathrm{Cr},{ }^{53} \mathrm{Cr}$, and ${ }^{54} \mathrm{Cr}$, with ${ }^{52} \mathrm{Cr}$ being the most abundant (83.789\% natural abundance) and is the $21^{\text {st }}$ commonly abundant element in Earth's crust at around a hundred ppm $[49,50]$. $\mathrm{Cr}(\mathrm{III})$ and $\mathrm{Cr}(\mathrm{VI})$ are the most commonly occurring oxidation states of chromium and are reported to be more toxic to animals, plants, and humans among its several oxidation states [50-54].

In a very simple and oxidizing medium, the trivalent chromium cation occurs only in a strongly acidic and decreasing medium, while hexavalent chromium occurs as $\mathrm{CrO}_{4}{ }^{2-}$ anion [55]. Chromium metal with various oxidation states exhibit different characteristics, including a metallic luster, brittle and tough, steely-grey color, tarnish resistance, and high melting and boiling points (1907 and 2671, respectively) [56]. Also, chromium belongs to the refractory metal group, which includes all metals with a melting point higher than platinum $\left(1,772^{\circ} \mathrm{C}\right)$. As a whole, chromium, the most known transition metal located in the $6^{\text {th }}$ group and $4^{\text {th }}$ period of the periodic table is abundant in the Earth crust and occurs as different stable isotopes and the various oxidation states of the metal determine its properties and characteristics.

2.2.2. Sources of Chromium. Chromium and associated chemical compounds can mainly originate naturally or anthropogenically.

(1) Natural Sources. From the two most stable oxidation state of chromium (i.e., $\mathrm{Cr}(\mathrm{III})$ and $\mathrm{Cr}(\mathrm{VI})$ ), the trivalent one exists naturally in a complex form with the chromite ore ( $\mathrm{FeCr} 2 \mathrm{O} 4)$, a mineral which exists in mafic and ultramafic rocks and is a complex of varying proportions of magnesium, iron, aluminum, and chromium [57-60]. The naturally released $\mathrm{Cr}(\mathrm{III})$ ion can most probably oxidize into a highly toxic form (i.e., $\mathrm{Cr}(\mathrm{VI})$ ) through microbial intervention and geochemical processes $[57,60]$. Also, geologic parent materials or rock outcroppings and volcanoes are the most significant natural source of chromium pollution in the environment [61]. Chromium in rocks, mineral soils, and freshwater is usually a dispersed geochemical component. $\mathrm{Cr}$ is also present in all sorts of environmental elements, including air, water, and soil, of course, but in limited amounts $[46,62,63]$.

(2) Anthropogenic Sources. Besides the existing natural process, various industrial activities produce chromium into the water bodies which have been a great threat for aquatic and terrestrial life and continued to be a concern of many researchers worldwide. Accordingly, many industrial processes employ chromium and its compounds for varied purposes. Among those manufacturing industries metallurgical, refractory, oil well drilling, metal plating, mining, textile, pulp, petroleum, chemical production, and leather consume chromium in varied amounts for different applications [64-69]. Among the most commonly existing oxidation states, $\mathrm{Cr}(\mathrm{VI})$ concentrations have increased dramatically in both marine and terrestrial ecosystems over 


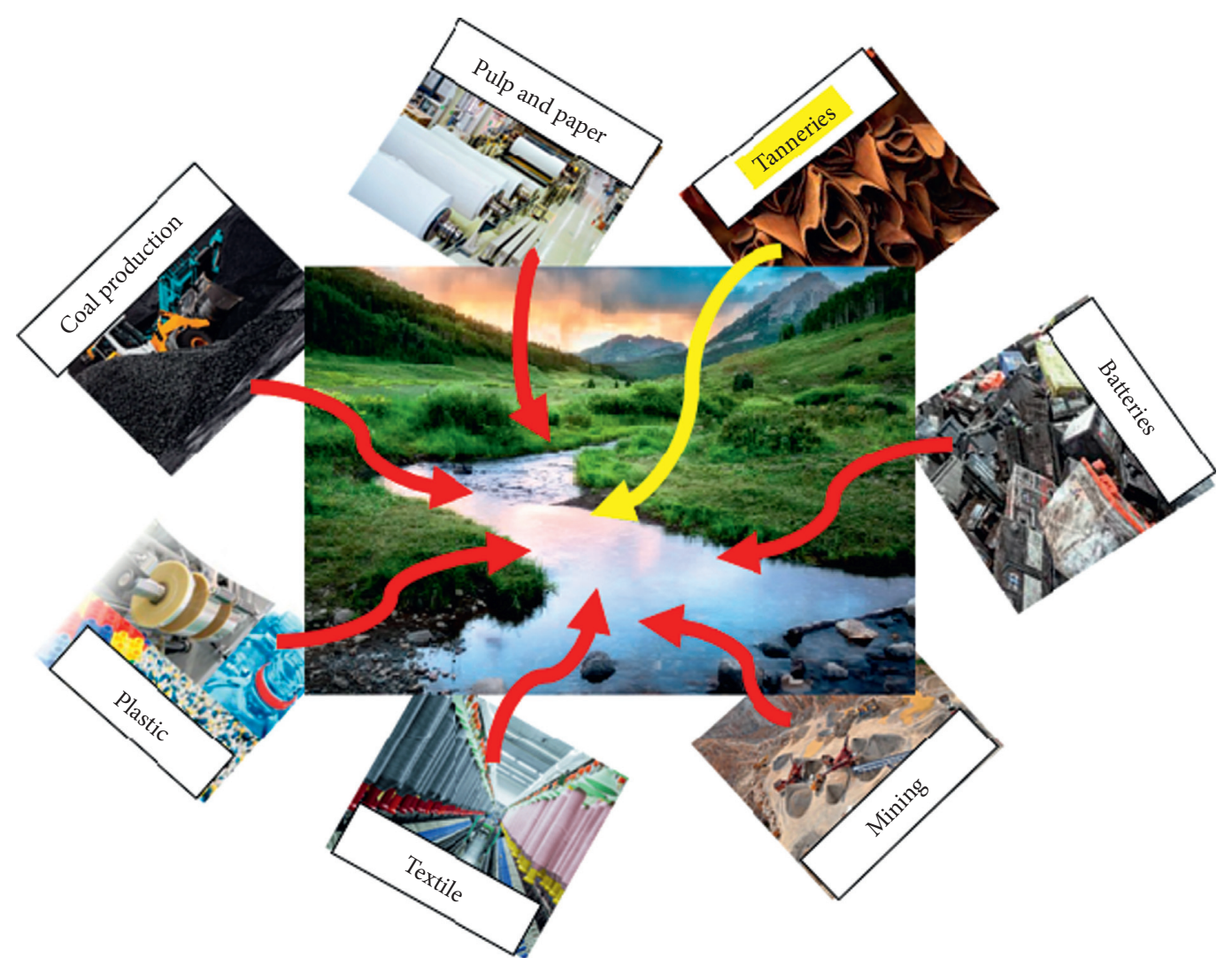

FIgURE 1: Different industrial activities discharging various heavy metals to the water systems [9, 11, 38, 39].

the past few centuries. It originates mainly from dyeing, textiles, steel fertilizers, photography, electroplating, manufacturing, packaging, and leather tanning and finishing [70].

In general, the most stable species of chromium, $\mathrm{Cr}$ (III) and $\mathrm{Cr}(\mathrm{VI})$, are produced both naturally and anthropogenically. The former one is mainly produced naturally by rock weathering, volcanic activities, and other geologic process, which gets oxidized to highly toxic $\mathrm{Cr}(\mathrm{VI})$ form by microorganisms in the environment. The hexavalent form highly produced through anthropogenic process by human activities rather than natural process.

\subsubsection{Oxidation States of Chromium. Chromium may exist} between 0 and VI in a variety of chemical varieties; however, trivalent and hexavalent chromium alone is sufficiently stable to occur in the environment [71, 72]. Chromium occurs in various chemical forms in soil (primarily as chromite $(\mathrm{Cr}(\mathrm{III}))$ and chromate $(\mathrm{Cr}(\mathrm{VI}))$, which vary greatly in terms of their biogeochemical actions [50]. Chromium species are commonly present in environmental water in two separate oxidation states, especially $\mathrm{Cr}(\mathrm{VI})$ and $\mathrm{Cr}(\mathrm{VI})$, with contrasting physiological effects. $\mathrm{Cr}(\mathrm{III})$ is considered to be an important trace element for the maintenance of the efficient metabolism of glucose, lipids, and proteins in mammals. Chromium at 0 oxidation state does not exist naturally in the Earth's crust and biologically inert, while $\mathrm{Cr}(\mathrm{II})$ can be easily oxidized into $\mathrm{Cr}$ (III) in the presence of air and is chemically unstable [73, 74]. This implies that different oxidation states of chromium have possessed varied properties and toxicity. On the other hand, $\mathrm{Cr}(\mathrm{VI})$ may be toxic and cancerogenic to human biological systems. Therefore, speciation of $\mathrm{Cr}(\mathrm{VI})$ and $\mathrm{Cr}(\mathrm{III})$ is important to determine toxicological actions $[75,76]$. In general, though chromium exists in various oxidation states ( 0 to VI), only the trivalent and hexavalent forms are relatively more stable, and the difference in the oxidation state led to variation in properties and toxicity of the metal.

2.2.4. Importance of Chromium. Despite their toxicity, carcinogenicity, and environmental threats at elevated concentrations, chromium and its compounds at a limited amount are applied for various purposes in different units. For instance, $\mathrm{Cr}(\mathrm{VI})$ and its compounds have been employed as pigments for photography and pyrotechnics, electroplating, tanning, textile production, coloring, painting, inks, wood preservation, and plastics [77, 78]. Besides, chromium and its preparations are widely used in many industrial processes such as chrome plating, wood preservation, textile dyeing, pigmentation, chemical production, paper, and tanning [79-81]. As laboratory reagents and as production intermediates, chromium compounds, such as hexavalent chromium, are documented. The metallurgical, chemical, and refractory brick industries are major industries that use chromium. Chromium is distinguished by its high resistance to corrosion and its hardness. Thus, the 
invention that steel could well be made to be extremely resistant to corrosion and discoloration by adding $\mathrm{Cr}$ to render stainless steel was a serious advancement. Besides $\mathrm{Cr}$ electroplating, this application is the highest volume user of the metal. The ore produces $\mathrm{Cr}$ and ferrochromium. $\mathrm{Cr}(\mathrm{VI})$ salts are used for timber preservation because of their toxicity [71]. In general, $\mathrm{Cr}$ in the industry is commonly used in plating, alloying, animal hide tanning, water corrosion inhibition, textile dyes and mordants, pigments, ceramic glazes, refractory bricks, and pressure-treated lumber [82].

Besides various industrial and laboratory applications, chromium, particularly trivalent chromium is nutritionally useful at the trace level. For example, a wide range of nutrients, such as coffee, nuts, green beans, egg yolks, whole-grain products, high-bran breakfast cereals, broccoli, meat, Brewer's yeast, and some brands of wine and beer are enriched with trivalent chromium [81, 83]. The recommended daily consumption of chromium according to the United State National Academy of Sciences is $50-200 \mu \mathrm{g}$ for adult men and women [81], but this range was recently lowered to $35 \mu \mathrm{g}$ and $25 \mu \mathrm{g}$ for adult men and women, respectively, according to Food and Nutrition Board at the Institute of Medicine [84]. However, more recently, the European Union of Food and Safety Administration had put weekly acceptable intake only, which is $300 \mu \mathrm{g} / \mathrm{kg}$ of body weight per week [85]. It has been documented that chromium is important in protein, carbohydrate, and lipid metabolism, and its deficiency leads to glucose intolerance and insulin resistance $[84,86]$. With this regard, daily intake of chromium at a reduced concentration (trace level) is associated with different medical applications. For instance, daily consumption of low to moderate amount of chromium helps fight against type II diabetes and obesity $[83,84,86]$, and chromium-containing alloy has also dental applications such as restoration, orthodontic appliances, and implants [83]. As a whole, chromium and its compounds are extensively used in different industrial activities and as reagents in laboratories, and in trace amount, the trivalent form is important candidates in nutrition.

2.2.5. Chromium Exposure and Toxicity. Chromium and its compounds, particularly chromates, enter into the human body through different pathways. Accordingly, inhalation, ingestion, and dermal contacts are the major integral exposure routes for chromium, and the exposure may be acute (14 days), intermediate (75-364 days), or chronic (365 days) $[47,87]$. Moreover, anthropogenically released chromium causes toxic effects in most exposed populations by inhalation of polluted air or drinking of chromium contaminated water $[88,89]$. Owing to its characteristic toxicity and carcinogenicity, the United State Environmental Protection Agency (US-EPA) and US Occupational Safety and Health Administration (OSHA) have put the total chromium exposure limits for drinking water standards which are $100 \mu \mathrm{g} /$ $\mathrm{L}$ and $\mathrm{Cr}(\mathrm{VI})$-timed weighted average for a normal workday exposure which is $5 \mu \mathrm{g} / \mathrm{L}$ [89]. Furthermore, the concentration of $0.510^{-4} \mu \mathrm{g} / \mathrm{L}$ is the maximum permissible limit for the discharge of total chromium into the surface and portable water according to US-EPA and European Union [90].
The pattern of toxicity and accumulation of heavy metals in the atmosphere is a significant danger to the health of living organisms [15]. Heavy metal exposure has been one of the big global concerns due to its high toxicity, high bioaccumulation in the human body and food chain, the essence of nonbiodegradability, and most likely human carcinogenicity [12]. Among various heavy metals ions, the most stable chromium species $(\mathrm{Cr}(\mathrm{III})$ and $\mathrm{Cr}(\mathrm{VI})$ ) are known to be toxic to aquatic and terrestrial life of which the hexavalent form is reportedly highly toxic and carcinogenic. The toxic, mutagenic, and other biological effects of chromium depend on its oxidation states. Accordingly, hexavalent chromium $\mathrm{Cr}(\mathrm{VI})$ is more harmful, cancerous, teratogenic, mutagenic, and movable than trivalent chromium $\mathrm{Cr}(\mathrm{III})$ because of its oxidizing existence [91, 92]. Even though the trivalent form is less toxic relatively, it induces its harmfulness by oxidizing into the most toxic hexavalent form in the presence of oxygen in the environment [65]. According to [47], the exposure to dichromate and chromates, which are oxyanion of chromium in +6 oxidation states and trivalent chromium released from alloys and Cr-plated objects, can cause dermatitis in humans. In synthetic pigment and industrial wastewater, Galvanometry and electricity, film and photography, plating and electroplating, metal washing, mining, and leather, chromium is the primary contaminant [93].

Chromium, especially, the hexavalent species poses its toxic effect through different mechanisms of actions. Among those, reducing activity or efficiency of the immune system; competing at enzyme activity cofactor fixation sites; inhibiting important enzymes such as oxidative phosphorylation and altering cell structures, mainly in the lipoprotein area of the membrane, are the key ones. Hexavalent chromium demonstrates high toxicity through its DNA-polymerase enzyme interface due to nasal irritation and ulceration, hypersensitivity reactions and contact dermatitis, acute bronchitis and emphysema, liver and kidney injury, internal hemorrhage, lung and skin cancer, and DNA damage [90]. Cr(VI) more readily enters the cell, but transfers multiple processes in the blood and gets reduced into $\mathrm{Cr}(\mathrm{III})$ in the human body [47]. $\mathrm{Cr}(\mathrm{VI})$ is removed from the body, while the chromate ion is transferred to the cell through a transport mechanism by which sulfate and phosphate ions also join the cell [52]. The presence of these ions in a cell can trigger oxidative stress, which is highly responsible for several chronic, neurodegenerative, cardiovascular, and other age-related diseases. In general, the augmented levels of oxidative stress, DNA adduct development, and chromosome breakups are some of the major mechanisms by which $\mathrm{Cr}(\mathrm{VI})$ cause cellular damage [89]. In due course, humans are exposed to chromium through ingestion, inhalation, and derma contact, and the exposure may be acute, intermediate, or chronic in general.

2.2.6. Toxic Effects of Chromium in Humans. Based on the epidemiological studies linking $\mathrm{Cr}(\mathrm{VI})$ to lung cancer, the International Agency for Research on Cancer (IARC) of the World Health Organization (WHO) classified $\mathrm{Cr}(\mathrm{VI})$ 
compounds as group one human carcinogens with multiple complex mechanisms of actions [89, 94, 95]. Human exposure to $\mathrm{Cr}(\mathrm{VI})$ can cause allergies, irritations, eczema, ulceration, nasal and skin irritations, eardrum perforation, respiratory tract disorders, and lung cancer [96]. $\mathrm{Cr}(\mathrm{VI})$ exposure may lead to cytotoxicity, genotoxicity, and carcinogenicity of $\mathrm{Cr}(\mathrm{VI})$-containing compounds, DNA mutations, and chromosomal damage at different stages, as well as to oxidative protein changes $[47,81,97,98]$. In addition, inhaling a high level of hexavalent chromium can cause nose ulcer, irritation to the lining of the nose, anemia, irritation and ulcer in the small intestine and stomach, as well as other respiratory complications such as wheezing, coughing, nasal blockage, and facial erythema [13, 87, 99]. Eventually, repeated and high exposure of chromium and associated compounds, especially those containing hexavalent ions can severely cause several hazards, of which most are categorized under those stated in Figure 2.

\subsubsection{Toxic Effects of Chromium in Microorganisms.} Biologically, chromium ions are important nutrients as they involve in electron transport reaction in biological systems; however, microorganisms are also highly sensitive to both deficiency and excessiveness of chromium and its compounds just like plants and humans [61]. Chromium toxicity affects microbial population size, diversity, and behavior, as well as their genetic structure. Microorganism exposure to hexavalent chromium can cause alteration in morphology of both Gram-positive and Gram-negative bacteria. It disturbs the morphology, metabolism, and growth of microorganisms by altering the structure of nucleic acid, disrupting the cell membranes, causing functional damage, inhibiting enzyme activity and oxidative phosphorylation, and causing lipid peroxidation and osmotic balance [15]. Chromium causes bacterial cell elongation and cell enlargement and prevents cell division, which is essentially responsible for cell growth inhibition [61]. In general, both shortage and exorbitance of chromium can cause adverse effects in microorganisms such as disruption of the growth and cell functions are retarded.

2.2.8. Toxic Effects of Chromium in Plants. Chromium compounds released naturally and/through different anthropogenic activities have been continuously discharged into the soil, in which different flora grow. Chromium compounds most commonly exist in the soil in the form of $\mathrm{HCrO}_{4}{ }^{-}$and $\mathrm{CrO}_{4}{ }^{2-}$ which get easily absorbed by the plants and rapidly trickled down into the deep layers of soil, thereby endorsing surface and groundwater pollution [85]. Among various oxidation states, $\mathrm{Cr}(\mathrm{III})$ is considered to be less harmful, preventing its leaching into groundwater or its absorption by plants due to its extremely low solubility, while $\mathrm{Cr}(\mathrm{VI})$ has been shown to cause substantial harm to living cells [100]. Although some crops are not affected by low levels of $\mathrm{Cr}\left(3.810^{-4} \mu \mathrm{M}\right)$ [101], chromium compounds are highly toxic to most plants and are harmful to their production and growth. But $\mathrm{Cr}(\mathrm{VI})$ can be extremely poisonous to plants in concentrations as little as $5 \mathrm{mg} / \mathrm{kg}$ in

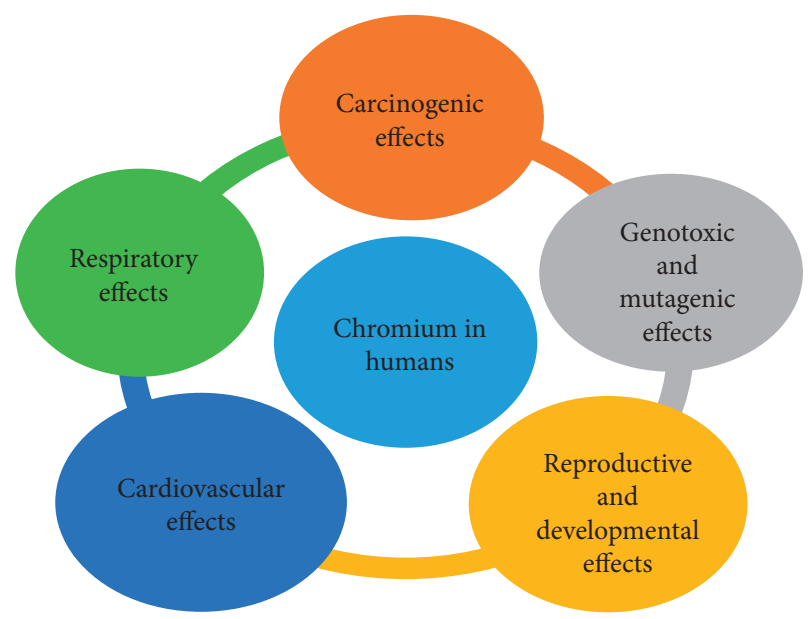

FIgUre 2: Toxicological effects of chromium on humans [61].

soils and $0.5 \mathrm{mg} / \mathrm{L}$ in solution according to Elahi et al. [85]. A reduction in nutrient uptake and photosynthesis is also correlated with $\mathrm{Cr}(\mathrm{VI})$, which contributes to slow plant growth. Several physiological, morphological, and biochemical processes are seriously disrupted and cause the production of reactive oxygen species in plant cells. $\mathrm{Cr}$ toxicity is indicated in the form of chlorosis and plant necrosis [62]. The major toxic effects of chromium in plants are summarized in Figure 3.

Chromium also affects the growth of leaves, the main photosynthetic plant organ. Increasing chromium concentration leads to a significant reduction in the leaf area and leaf biomass, which is accompanied by decreased photosynthesis and induction of chlorosis and necrosis of leaves. Under Cr exposure, many destructive processes take place in leaves. These include suppression of chlorophyll synthesis, disruption of chloroplast ultrastructure, inhibition of photosynthetic electron transport, and release of magnesium ions from the molecule of chlorophyll [102]. Symptoms of $\mathrm{Cr}(\mathrm{VI})$ poisoning in plants include reduced plant growth, leaf deformation and necrosis, 88 chlorosis, decreased enzyme activity and nutrient absorption and transport, damage to root tissue, decreased photosynthesis, lipid peroxidation, DNA strand break, and chromosome aberration [81, 103]. Thus, chromium can inhibit photosynthesis, seed germination, and nutrient uptake and affect the growth and functionality of its parts in general.

\section{Chromium Removal Methods}

Several methods of removing heavy metals from polluted water have been used [104-107]. Heavy metals such as chromium have been removed from polluted environments such as wastewater via several conventional physicochemical procedures such as chemical precipitation, electrolysis, ion exchange, floatation, coagulation and flocculation, membrane filtration, reverse osmosis, adsorption, and photocatalysis [56, 108-114]. The removal of chromium by such traditional methods are inefficient during the reduction of heavy metals at very low concentrations of $10-100 \mathrm{mg} / \mathrm{L}$ so that the metal ions are not completely removed and also the 


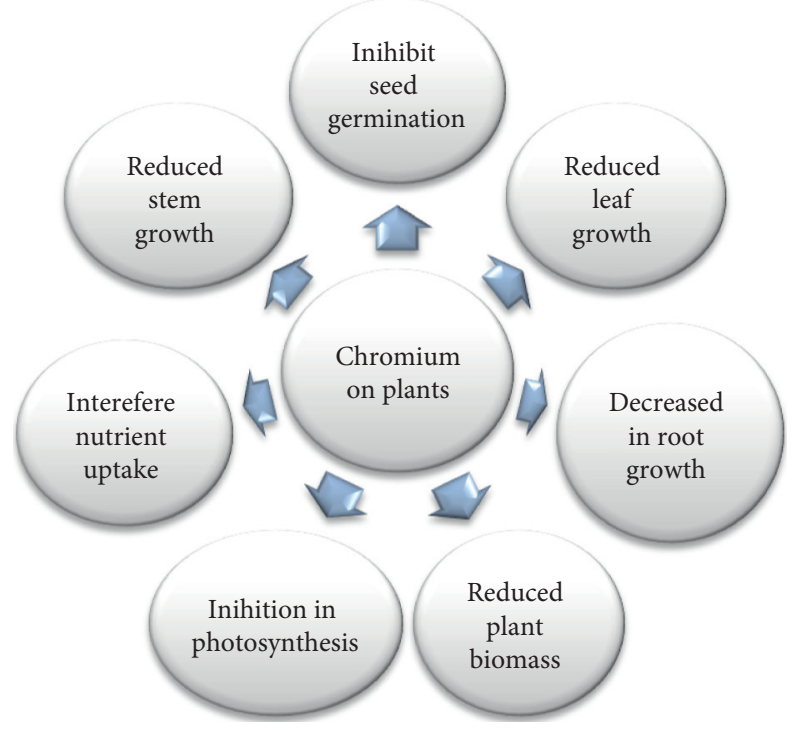

FIgURE 3: Toxic effects of chromium in plants [50].

methods are very costly $[109,115,116]$. In addition, these conventional methods generate large quantities of secondary waste (sludges) and other toxic products that may require other technologies to be brought to nontoxic, biodegradable, and environmentally benign forms.

Consequently, the focus has been shifted to biological remediation approaches having relatively high removal efficiency, less cost and environmentally benign. Biotransformation and biosorption are widely used technologies that utilize the ability for heavy metal transformation or adsorption by microorganisms or plants $[56,117]$. Technologies for the biological removal of heavy metals use biomass to remove chromium from industrial waste and are costeffective, environmentally safe and easy to operate $[56,118]$. The alternative and environmentally sustainable form of chromium biosorption is the biological one. Potential biological methods (i.e., biosorption, bioaccumulation, oxidation/reduction, leaching, precipitation, volatilization, decay, and phytoremediation) have been employed to remove and detoxify toxic heavy metals from contaminated water and sediments. In addition, the options for the recovery of metals sequestered by biosorbents (use of suitable desorbing agents) and microbial biomass are identified [119]. Though different chemical and physical methods have been applied as removal technique, the biological remedy using microorganisms attracted the attention due to economic feasibility, simplicity, efficiency, and production of less or no secondary wastes in general.

3.1. Biological Method of Chromium Removal. The biological method of heavy metal removal involves the decomposition and/reduction of toxic heavy metal ions to relatively less and/nontoxic forms by using the living and/or dead biomass of microorganisms (such as bacteria, fungi, algae, and yeast), industrial or agricultural wastes, naturally occurring materials (such as clay, chitin, chitosan, lignin, and zeolite), and different parts of plants. A potentially useful method for the detoxification of $\mathrm{Cr}$ contamination and bioremediation of polluted waste is the biological reduction of $\mathrm{Cr}(\mathrm{VI})$ to $\mathrm{Cr}(\mathrm{III})$ [100]. Chromium removal by microbial species is a sustainable development solution that is healthy and environmentally friendly. These techniques are conceivably employed by using different microbial biomass mainly bacteria, fungi, and algae. The biosorption of $\mathrm{Cr}(\mathrm{VI})$ using fungal, algal, or bacterial biomass (growing, resting, and dead cells) and biological and agricultural waste materials has been described as a possible alternative to the current conventional methods of industrial wastewater detoxification [20]. Chromium-resistant microorganisms are responsible for/to the biological reduction of $\mathrm{Cr}(\mathrm{VI})$ to less mobile $\mathrm{Cr}(\mathrm{III})$, and their consequent precipitation may be an important method of detoxification of polluted $\mathrm{Cr}(\mathrm{VI})$ sites and have a possible application for bioremediation [96]. Microorganisms remove heavy metals in such a way that they utilize metal ions for their advancement and by converting them into carbon dioxide, methane, water, and biomass through enzyme-catalyzed metabolism of poisonous substances [120].

In the microbial remediation process, microorganisms (such as bacteria, fungi, algae, and yeasts) are stimulated to readily degrade the environmentally toxic pollutants to ecofriendly or safe levels in soil, subsurface materials, water, sludge, and residues [35]. It has been reported that different microbial remediation techniques such as biosorption, bioaccumulation, biotransformation, and bioleaching have been employed to remove chromium and other heavy metals from industrial wastewaters [92]. The bioremediation process recently reported as the dominant friendly mechanism for heavy metal removal from a polluted environment is summarized in Figure 4. Bioaccumulation, also called active biosorption, is a metabolism-dependent mechanism in which hexavalent chromium $(\mathrm{Cr}(\mathrm{VI}))$ is transported across the membrane into the cell by cellular energy in living biomass only [92]. The bioaccumulation process occurring in living microorganisms involves the following steps $[56,121]$. Initially, potentially toxic heavy metal ions get attached to the surface ligand of the cell. Then, the metalligand complex formed at the surface of the cell is transported inside the cell by transporter protein. Finally, transported complexes intracellularly interact with metalbinding proteins (such as metallothionein and phytochelatins), where precipitation, methylation, and other process takes place. However, the process is limited to the living cells only and inhibits microbial cell growth at a relatively higher metal concentration [92]. Finally, the living and dead microbial biomass, mainly that of bacteria, fungi, and algae ecofriendly degrade and remove toxic chromium ions by the process of biosorption, biotransformation, and bioaccumulation.

3.1.1. Reduction of Cr(VI) to Cr(III). As it has been discussed in preceding sections, hexavalent chromium is more toxic to plants, animals, and aquatic species when compared to the trivalent species. Hence, transforming the more toxic $\mathrm{Cr}(\mathrm{VI})$ species from the solution to the less toxic one can take place 


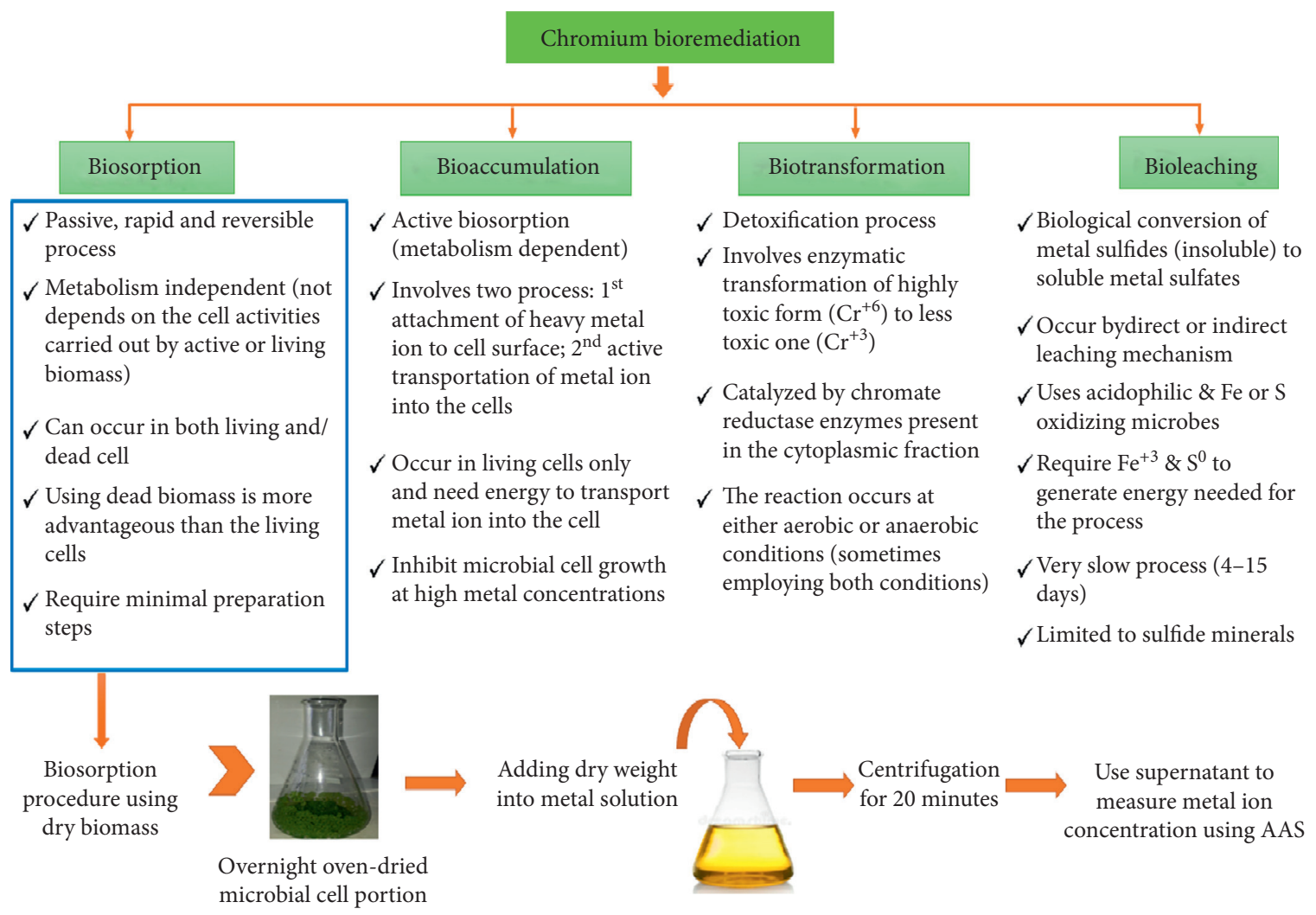

FIGURE 4: Heavy metal bioremediation processes by microorganisms [87, 92, 121-123].

by different process through varied conditions. In addition to extracellular adsorption and intracellular accumulation, $\mathrm{Cr}(\mathrm{VI})$ can importantly transform and reduce to less toxic Cr(III) species by chromium reductase enzyme [63, 124]. More importantly, the biomass surface with electron donating agents such as hydroxyl groups, amine groups, and secondary alcohol groups interact with $\mathrm{Cr}(\mathrm{VI})$ favorably at acidic $\mathrm{pH}$ and is reduced to $\mathrm{Cr}(\mathrm{III})$, which subsequently binds to the negatively charged functional groups (such as sulfonate group and carboxyl group) [7]. Even though the reduction of hexavalent chromium to the trivalent one most of the time takes place in living biomass, it has also been observed in nonliving microalgae biomass, which might due to the release of glutathione [63]. In this regard, $\mathrm{Cr}(\mathrm{VI})$ reduction at acidic $\mathrm{pH}$ condition using dead microalgae biomass is as follows [125].

Therefore, in addition to biosorption and bioaccumulation, hexavalent chromium can also be removed from aqueous solution by being enzymatically reduced and transformed in to less toxic species (such as $\mathrm{Cr}(\mathrm{III})$ ) by living or dead microbial biomass at different favorable conditions.

3.1.2. Hexavalent Chromium (Cr(VI)) Biosorption. In contrast to the bioaccumulation process, biosorption is a metabolism-independent mechanism, which can occur in both living cells (but not depend on cell activities) and dead microbial biomass [92, 120, 121, 126]. In biosorption mechanisms, the toxic heavy metal ions such as $\mathrm{Cr}(\mathrm{VI})$ extracellularly bind to various functional groups of the microbial cell wall (as shown in Figure 5), which are removed either by surface precipitation, ion exchange, or complexation/chelation process $[92,121,127]$. The compositions and structures of the cell wall vary across different microorganisms. For instance, the bacterial cell wall composed mainly of peptidoglycan [128], but that of fungi is glucans, chitin, glycoproteins, melanin [129], and the algae cell wall is composed mainly of alginate, mannans, and sulfonated polysaccharides [130].

Hence, the extensive mechanism for the biosorption process is very complex since it depends on the types of biomasses going to be used, the functional groups of the microbial cell wall, its structure, and extracellular polymer substances secreted by microorganisms [131-133]. The biosorption process is reported to have various advantages over other bioremediation mechanisms for toxic heavy metal removal from polluted environments. The presence of multifunctional groups and uniform distribution of binding sites on the cell surface, no need for additional nutrients (chemicals), minimal preparatory steps, low cost, high efficiency, regeneration of biosorbent, and possibility of metal recovery are some advantages of the biosorption process $[90,121]$. Owing to these and other related advantages, the focus has been given to the biosorption process using different microbial biomass such as bacteria, fungi, and microalgae for the removal of heavy metals particularly hexavalent chromium. Different microbial 


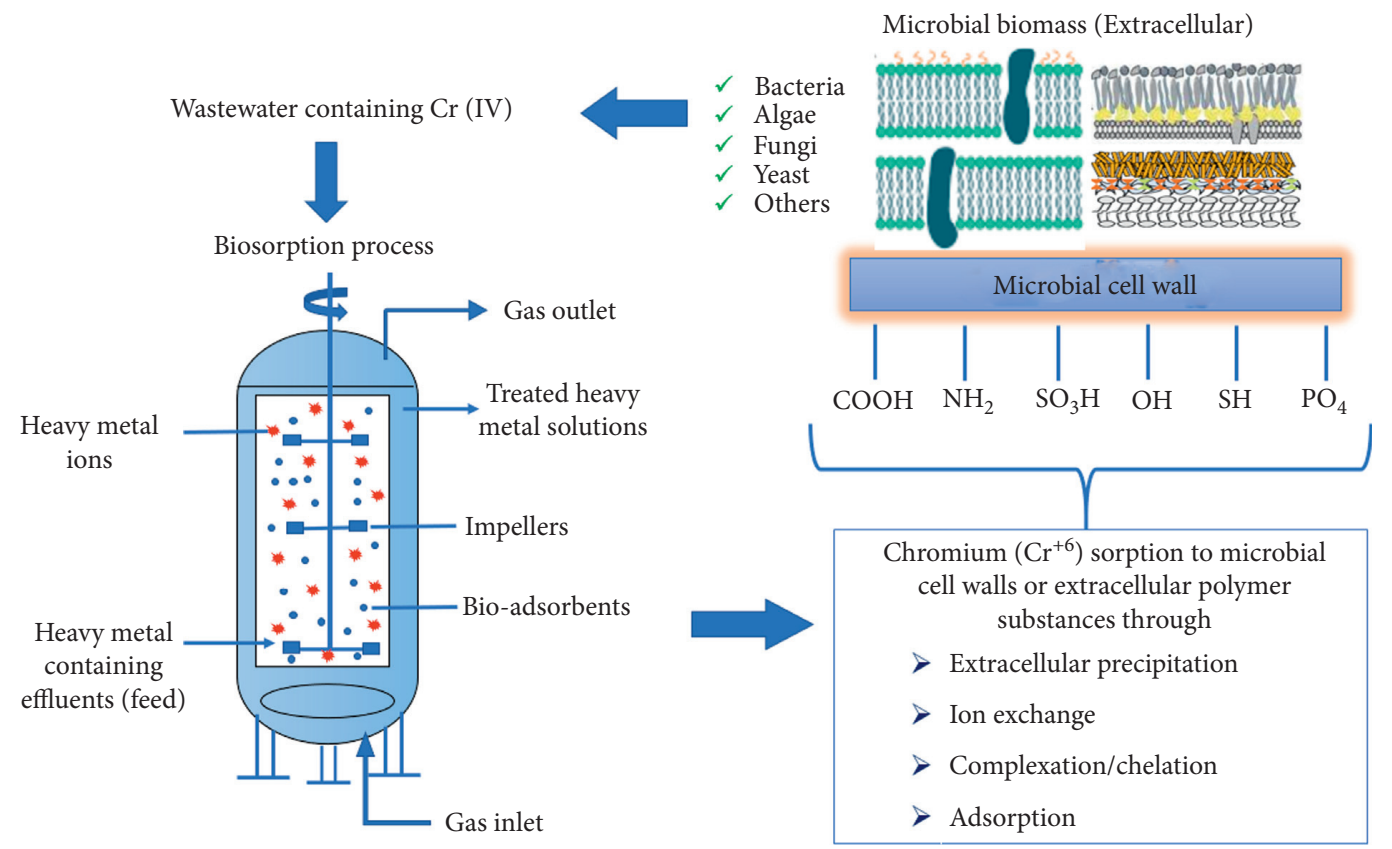

FIGURE 5: Hexavalent chromium (Cr(VI)) biosorption process by microorganisms [90].

TABLE 1: Various microorganisms used for biosorption of chromium.

\begin{tabular}{|c|c|c|c|c|c|c|c|}
\hline \multicolumn{8}{|c|}{ Bacteria } \\
\hline S.No. & Species & $\mathrm{IC}(\mathrm{mg} / \mathrm{L})$ & Dose $(\mathrm{g} / \mathrm{L})$ & $\mathrm{pH}$ & $\begin{array}{l}\text { Time } \\
(\mathrm{hr})\end{array}$ & \% Removal & References \\
\hline 1 & Bacillus salmalaya & - & - & 3 & 0.83 & $20.35 \mathrm{mg} / \mathrm{g}$ & [134] \\
\hline 2 & Bacillus sp. & - & - & - & 72 & 75 & [135] \\
\hline 3 & Bacillus spp. & 1 & 0.25 & 2 & 5 & 99 & {$[110]$} \\
\hline 4 & Enterobacter cloacae & 0.001 & - & - & 120 & 81 & [19] \\
\hline 5 & Chelatococcus daeguensis & 15 & - & 7 & 24 & 94.42 & [136] \\
\hline 6 & Micrococcus sp. & 100 & - & 7 & 24 & 90 & [137] \\
\hline 7 & Planococcus sp.VITP21 & 142.8 & - & 6.8 & 12 & 83 & {$[138]$} \\
\hline 8 & Pseudomonas alcaliphila NEWG-2 & 200 & - & 7 & 48 & 96.60 & [139] \\
\hline 9 & Halomonas sp. DK4 & 100 & - & 6 & 48 & 81 & {$[140]$} \\
\hline 10 & Klebsiella sp & 100 & - & 9 & 72 & 63.08 & [141] \\
\hline 11 & Sinorhizobium sp. SAR1 & - & 7.5 & 1 & - & $285.71 \mathrm{mg} / \mathrm{g}$ & {$[142]$} \\
\hline \multicolumn{8}{|c|}{ Fungi } \\
\hline 1 & $\begin{array}{c}\text { Consortium of Penicillium commune, Paecilomyces lilacinus, } \\
\text { Cladosporium perangustum, Cladosporium perangustum, and } \\
\text { Fusarium equiseti }\end{array}$ & - & - & 4 & 24 & 100 & {$[143]$} \\
\hline 2 & Fusarium sp & - & - & - & - & 100 & {$[144]$} \\
\hline 3 & Aspergillus Niger & 18.125 & 4 & 3 & 168 & 96.3 & {$[145]$} \\
\hline 4 & Aspergillus flavus & 18.125 & 4 & 3 & 168 & 92.8 & \\
\hline 5 & Aspergillus fumigatus & 18.125 & 4 & 3 & 168 & 90.1 & \\
\hline 6 & Aspergillus nidulans & 18.125 & 4 & 3 & 168 & 86.7 & \\
\hline 7 & Aspergillus heteromorphus & 18.125 & 4 & 3 & 168 & 83.7 & \\
\hline 8 & Aspergillus foetidus & 18.125 & 4 & 3 & 168 & 78.6 & \\
\hline 9 & Aspergillus viridinutans & 18.125 & 4 & 3 & 168 & 74.4 & \\
\hline 10 & $\begin{array}{l}\text { Consortium of Aspergillus lentulus, Aspergillus terreus, and } \\
\text { Rhizopus oryzae }\end{array}$ & 100 & - & 6.5 & 96 & 100 & {$[146]$} \\
\hline 11 & Aspergillus lentulus & 100 & - & 6.5 & 120 & 83.11 & \\
\hline 12 & Aspergillus terreus & 100 & - & 6.5 & 96 & 95.57 & \\
\hline 13 & Rhizopus oryzae & 100 & - & 6.5 & 168 & 25.34 & \\
\hline 14 & Aspergillus versicolor & 50 & - & 6 & - & 99.89 & [147] \\
\hline 15 & Rhizopus oryzae & 400 & - & 7 & 72 & 91.15 & [148] \\
\hline
\end{tabular}


TABLE 1: Continued.

\begin{tabular}{|c|c|c|c|c|c|c|c|}
\hline \multicolumn{8}{|c|}{ Bacteria } \\
\hline S.No. & Species & $\mathrm{IC}(\mathrm{mg} / \mathrm{L})$ & Dose $(\mathrm{g} / \mathrm{L})$ & $\mathrm{pH}$ & $\begin{array}{l}\text { Time } \\
\text { (hr) }\end{array}$ & \% Removal & References \\
\hline 16 & Aspergillus sp & 100 & - & 5 & 24 & 92 & [137] \\
\hline 17 & Cladosporium cladosporioides & 504 & 0.5 & 1 & 288 & $491.85 \mathrm{mg} / \mathrm{g}$ & [149] \\
\hline 18 & Trichoderma sp. & 200 & 0.0016 & 5 & 2 & 96.38 & {$[150]$} \\
\hline 19 & Aspergillus terreus & 1000 & 10 & 1 & 24 & 54 & {$[151]$} \\
\hline 20 & Pleurotus ostreatus & 50 & - & - & 0.367 & 100 & {$[152]$} \\
\hline 21 & Pleurotus ostreatus & - & 0.2 & 5 & 2 & 20.71 & [153] \\
\hline \multicolumn{8}{|c|}{ Microalgae } \\
\hline 1 & Scenedesmus sp. & 10 & $10 \%(\mathrm{w} / \mathrm{v})$ & 1 & 1.5 & 92.89 & {$[154]$} \\
\hline 2 & Pseudanabaena mucicola & - & - & 2 & - & 71 & {$[155]$} \\
\hline 3 & Pseudopediastrum boryanum & 10 & 2 & 2 & - & 70 & [112] \\
\hline 4 & Scenedesmus sp. & - & - & - & - & 98 & {$[156]$} \\
\hline 5 & Chlorella colonials & 6.07 & 2.7 & & 108 & 97.8 & {$[157]$} \\
\hline 6 & Chlorella sorokiniana & 100 & 0.2 & 6.2 & 72 & 99.6793 & {$[158]$} \\
\hline 7 & Chlorella sp. & - & - & - & 96 & 34 & [159] \\
\hline 8 & Chlorella vulagris & 100 & 1.2 & 3 & 1 & 99.75 & {$[160]$} \\
\hline 9 & Scenedesmus sp & 10 & $10 \%(\mathrm{w} / \mathrm{v})$ & 1 & 2 & 93.1 & [154] \\
\hline 10 & Spirulina platensis & 150 & 0.2 & 1 & 1.5 & $45.5 \mathrm{mg} / \mathrm{g}$ & {$[161]$} \\
\hline 11 & Isochrysis galbana, & - & $10 \mathrm{~mL}$ & 5 & 2 & $335.27 \mathrm{mg} / \mathrm{g}$ & [162] \\
\hline 12 & Chlamydomonas sp & 250 & 1.5 & 4 & 0.5 & 91 & [163] \\
\hline
\end{tabular}

biomass that has been employed for biosorption of chromium is summarized in Table 1.

The ability of microorganisms, for example, bacteria, fungi, and algae to remove heavy metal ions and, or to promote their transformation to less-toxic forms, has attracted the attention of various environmental scientists, engineers, and biotechnologists for many decades [10]. This is mainly because the process is simple, rapid, economical, and environmentally benign when compared to the physical or chemical techniques. In general, biosorption is metabolism-independent process, in which both living and dead cells can be used and the $\mathrm{Cr}(\mathrm{VI})$ ion extracellularly bind to various functional groups of the microbial cell wall, which are removed either by surface precipitation, ion exchange, or complexation/chelation process as typical mechanism.

3.2. Bacteria. Chromium removal by using bacterial strain is characterized as relatively rapid, economic, requires less energy, and the process requires less or no chemicals [62]. Bacterial species isolated from metal-contaminated environments are highly resistant to toxic heavy metals than those isolated from none-contaminated environments. Both Gram-positive and Gram-negative bacterial strain isolated from soil, water, and another chromate contaminated environment especially, effluents from tanneries and electroplating industries, has been employed for chromium biosorption $[90,164]$. However, at a relatively high concentration, Gram-positive bacteria showed significantly good tolerance to toxic $\mathrm{Cr}(\mathrm{VI})$ when compared to Gramnegative bacteria [164]. Different bacterial species recently employed for chromium biosorption are summarized in
Table 1. Due to their high surface-to-volume ratios and a high content of potentially active chemosorption sites such as teichoic acid in their cell walls, bacteria make outstanding biosorbent. Due to their small scale, their ubiquity, their capacity to grow under regulated conditions and their resistance to a broad variety of environmental circumstances, bacteria have been used as biosorbent. [165].

3.3. Fungi. Fungi are microbes that, due to the production of high biomass yields, are used as biosorbent for the removal of heavy metals. They are among the abundantly used microorganisms for biosorption of $\mathrm{Cr}(\mathrm{VI})$ since they are versatile, capable to adopt harsh environments, and can tolerate high hexavalent chromium concentration (above $10,000 \mathrm{mg} / \mathrm{L}$ ) [90]. Fungal species are usually immune to higher metal ion concentrations $[20,165]$. In fungi, $\mathrm{Cr}(\mathrm{VI})$ is adsorbed on the cell surface by forming a chemical bond with functional groups which are present on cell surface proteins [62]. The binding of hexavalent chromium to the fungal cell is owed to the chemical components, mainly proteins, lipids, and polysaccharides such as galactosamine, chitin and glycan, and the varieties of functional groups such as carboxyl $(-\mathrm{COOH})$, phosphate $\left(\mathrm{PO}^{3-}\right)$, amine $\left(-\mathrm{NH}_{2}\right)$, thiol $(-\mathrm{SH})$, and hydroxide $(-\mathrm{OH})$ groups [166]. Cr-fungi interactions have been extensively studied, mainly related to chromate tolerance in filamentous fungi and yeasts, and chromate reduction by yeasts. Fungi are usually less susceptible to metals than bacteria [66].

3.4. Microalgae. Algae are efficient and cheap biosorbents due to little nutrient requirement and their high productivities (i.e., high growth rate compared to the terrestrial 
plants and can complete an entire growing cycle in every few days) [167]. Based on statistical analysis on algae potentiality in biosorption, it has been reported that algae absorb about $15.3 \%-84.6 \%$ which is higher as compared to other microbial biosorbents [168]. Heavy metal uptake by microalgae encompasses passive biosorption by dead biomass and active biosorption by living microalgae cells. In the process of passive biosorption, metal ions in the cationic form are physically adsorbed over the microalgal cell surface that contains functional groups such as hydroxyl (-OH), carboxyl $(-\mathrm{COOH})$, amino $\left(-\mathrm{NH}_{2}\right)$, and sulfhydryl $(-\mathrm{SH})$. During active biosorption, the metal ions are translocated across the cell membrane into the cytoplasm [169]. The binding of heavy metal ions to microalgae biomass is owed to the presence of multiple functional groups such as carboxylic acid, ether, amide, hydroxyl, and other carbonyls [170]. Among various binding functional groups, deprotonated sulfate and carboxyl groups as well as the monomeric alcohol and laminarin, are most likely responsible for the biosorption process [171]. Depending on its speciation, there are reports of tolerance or resistance of a small number of algae to $\mathrm{Cr}$. The reduction of $\mathrm{Cr}(\mathrm{VI})$ to $\mathrm{Cr}$ (III) and reduced Cr uptake by algal cells is not likely to be involved in $\mathrm{Cr}$ (III) algal resistance [66].

In winding up, dead and living biomass of bacterial, fungal, and algal species are the most important, extensively used, relatively rapid, and economic process for removing toxic and hazardous metal ions like hexavalent chromium by biosorption.

\section{Factors Influencing Chromium Biosorption by Microorganisms}

4.1. The Influence of $p H$. It is a very important parameter. It affects the solubility of metal ions and binding sites of biomass [172]. Both biosorption and $\mathrm{Cr}(\mathrm{VI})$ reduction is dependent on the initial $\mathrm{pH}$ of the media. The carboxylic, phosphate, and amino groups are deprotonated at $\mathrm{pH}$ values greater than $\mathrm{pKa}$, and therefore, negatively charged surface functional groups are able to bind positively charged metal ions, but metal ions no longer attracted to the biomass as the carboxylic, phosphate, and amino groups become protonated at $\mathrm{pH}$ values less than $\mathrm{pKa}$ [173]. Since $\mathrm{Cr}(\mathrm{VI})$ reduction is a proton consumption process, there is an increment in $\mathrm{pH}$ with $\mathrm{Cr}(\mathrm{VI})$ reduction. Hence, $\mathrm{Cr}(\mathrm{VI})$ reduction is generally higher at low $\mathrm{pH}$ values [88]. Indeed, the biosorption of chromium is highly favored as chromium anions are electrostatically get attracted to the carboxyl and amino groups on the surface of biomass, which are protonated at lower $\mathrm{pH}$ [110]. According to Ozer et al. [174] Pediastrum boryanum biosorbents showed its maximum adsorption of $\mathrm{Cr}(\mathrm{VI})$ at $\mathrm{pH} 2.0$, but when the $\mathrm{pH}$ value raised, $\mathrm{Cr}(\mathrm{VI})$ removal efficiency was declined. This indicates that the $\mathrm{pH}$ of the reaction environment highly affects the heavy metal biosorption capacities of microbial biomass. The optimal conditions employed by different researchers to obtain good biosorption efficiencies by different microorganisms, mainly bacteria, fungi, and yeast biomass are given in Table 1 .
4.2. The Influence of Temperature. The temperature of the adsorption medium could be important for energydependent mechanisms in metal biosorption by microbial cells [175]. The temperature is an important parameter for bacterial growth, which affects the enzymatic reactions necessary for $\mathrm{Cr}(\mathrm{VI})$ reduction [176]. Growth and reduction of $\mathrm{Cr}(\mathrm{VI})$ is negatively affected by extreme temperature which arises from the reduction in viability or due to the arrest of the physiological activity of the cell. Higher temperature results in protein denaturation and DNA damage as well as change in the structure of the membrane [177]. According to [178], with an increase in the temperature range of 30 to 40 , the removal rate of $\mathrm{Cr}(\mathrm{VI})$ by strain Desulfovibrio CR-1 gradually increased to the same level, and the removal effect was best.

4.3. The Influence of Contact Time. Contact time is one of the most significant parameters for the effective use of the biosorbent for a practical application, and it has direct impact on the heavy metal removal efficiency. Metal ion removal efficiencies increase with increasing contact time and more or less remain constant after equilibrium achieved $[179,180]$. Biosorption occurs rapidly if equilibrium is optimally attained within a few hours [181]. The metal adsorption of chromium (VI) by Pantoea sp. TEM18 increased rapidly during the first $5 \mathrm{~min}$ and remained nearly constant after $15 \mathrm{~min}$. After this equilibrium period, the number of adsorbed metals ions did not significantly change with time [182].

4.4. The Influence of Initial Metal Ion Concentration. The initial concentration provides an important driving force to overcome all mass transfer resistance of metal between the aqueous and solid phases [172]. At higher concentrations, more chromium ions are left unabsorbed in the solution due to the saturation of binding sites [110]. The study done by [142] confirms that an increase in metal concentration, from $100 \mathrm{mg} / \mathrm{L}$ to $500 \mathrm{mg} / \mathrm{L}$, led to a decrease in percentage $\mathrm{Cr}(\mathrm{VI})$ removal (from $99.88 \%$ to $83.69 \%$ ). But analysis of total $\mathrm{Cr}$ showed that uptake capacity of the biosorbent SAR1 increased $(6.27 \mathrm{mg} / \mathrm{g}$ to $28.95 \mathrm{mg} / \mathrm{g})$ with an increase in $\mathrm{Cr}(\mathrm{VI})$ concentration.

4.5. The Influence of Biosorbent Dosage. The increase in the biosorbent concentration favors the heavy metal biosorption because of the increase in surface area [150]. According to [167], Cr(VI) removal efficiency by microalgae Scenedesmus species increased rapidly from 45.9 to $92.9 \%$ with the increase of S/L from 2 to $10 \%(\mathrm{w} / \mathrm{v})$, and on further increase up to $30 \%(\mathrm{w} / \mathrm{v})$ is slightly increased to $96 \%$.

4.6. The Influence of Agitation Speed. Agitation enhances dissolved oxygen or aeration which in turn strongly favors microbial growth and hence increases chromate reduction. However, there may be mechanical damage to microbial cells as a result of high agitation speed [88]. 
Generally, $\mathrm{pH}$, temperature, contact time, stirring speed, and adsorbent dosages are the major factors that highly influence the removal efficiency of chromium ions from the solutions. This means that efficient and maximum biosorption can take place at specified temperature, $\mathrm{pH}$, contact time, and dosage of adsorbent depending on the specific types of microbial biomass used.

\section{Mechanisms of Chromium Biosorption by Microorganisms}

Microbes are organisms that are capable of tolerating unfavorable circumstances, and these mechanisms evolved for the past millions of years. There are several protection mechanisms of heavy metal resistance by microbial cells. These mechanisms are an extracellular barrier, extracellular sequestration, and active transport of metal ions (efflux), intracellular sequestration, and reduction of metal ions [9]. The biological process of heavy metal removal can either be biosorption or bioaccumulation according to the cell's metabolism process [183, 184]. The two-bioremediation process differs mainly by the nature of sorbent, which in this case is the material of biological origin known as biosorbent. Bioaccumulation is a metabolism-dependent process in which the intracellular uptake of metal occurs due to increased membrane permeability. It can occur only with living organisms in which the contaminants are transported into the cell, and the metal ions are accumulated inside the cell of the biosorbent [183-185]. Biosorption, on other hand, is a quick, independent, and metabolically passive process responsible for the selective sequestration of heavy metal ions by dead/inactive biomaterials [183, 184]. During biosorption, the heavy metals bind to the cell walls extracellularly, while they bound to the proteins such as metallothionein once the metal ions are inside the cells in the bioaccumulation process.

The biosorption process always involves a solid phase which serves as the biosorbent (various biological materials). Due to the higher affinity of the sorbent for the sorbate species, the sorbate is attracted and bound thereby various mechanisms [181]. Biosorption is a nondirected physiochemical interaction that occurs between metal species and the cellular components of biological species. The mechanisms behind their resistance include adsorption, uptake, methylation, oxidation, and reduction of toxic, highly soluble $\mathrm{Cr}$ (VI) to less soluble and less toxic Cr(III) [186]. Heavy metal ions can be entrapped in the cellular structure of such organisms and subsequently be absorbed onto binding sites present on it (Figure 6). Biosorbents contain a variety of functional groups, including carboxyl, imadizole, sulfhydril, amino, phosphates, sulfate, thioether, phenol, carbonyl, amide, and hydroxyl moieties [181].

Microorganisms interact with metal ions through cell wall-associated metals, intracellular accumulation, metal siderophore, extracellular polymeric reactions with transformation, extracellular mobilization or immobilization of metal ions, and volatilization of metals [15]. As biosorption is a process in which physicochemical interaction between the charged surface groups of micro- organisms and ions in the solution takes place by the process of complexation, ion-exchange, microprecipitation, adsorption $[176,187]$. Metal sequestration or uptake in the case of bioaccumulation is followed by a number of processes such as localization of metal $(\mathrm{Cr})$ within cell components, metallothionein binding, metal accumulation, extracellular precipitation, and complex formation [88]. Microbial $\mathrm{Cr}(\mathrm{VI})$ removal typically involves three stages: binding of chromium to the cell surface, translocation of chromium into the cell, and reduction of $\mathrm{Cr}(\mathrm{VI})$ to $\mathrm{Cr}(\mathrm{III})$. In general, $\mathrm{Cr}(\mathrm{VI})$ reduction by $\mathrm{mi}^{-}$ croorganisms may proceed on the cell surface, outside the cell, or intracellularly, either directly via chromate reductase enzymes, or indirectly via metabolite reduction of Cr(VI) [188].

\section{Functional Groups Involved in Microorganisms during Biosorption of Chromium}

The functional group is one of the major determinant factors in studying the removal of heavy metals from a contaminated environment using biological methods. Identifying functional groups responsible for the binding metal ions to the microbial biomass is very helpful in determining the biosorption mechanism and also important to decide on the plausibility of biomass for the process. Biosorbent containing multiple functional groups are more plausible for biosorption as the presence of multiple binding sites widens more contaminants binding opportunities. The type, structure, and connectivity of functional groups may considerably vary from microorganism to microorganisms and most of these groups have been characterized mainly on the microbial cell walls. The functional groups such as aldehydes, alkyl chains, amide, amine, alcohols/phenols, carboxylic, ester, organic halide compounds, phosphate, sulfoxide, and aliphatic organic chains of cellulose were identified as functional groups for the biosorption of chromium [7].

According to Javanbakht et al. [189]; the microbial biomass with oxygen ( $\left.\mathrm{O}_{-}\right)$, nitrogen $\left(\mathrm{N}_{-}\right)$, sulfur $\left(\mathrm{S}_{-}\right)$, and/ phosphorus $(\mathrm{P}-)$ containing functional groups directly participate in the binding of certain metal ions. The active functional groups present in microbial cells that are responsible for metal ion binding and the adsorption isotherm followed is given in Table 2. Different spectroscopic and microscopic techniques, such as infrared and Raman spectroscopy, electron dispersive spectroscopy, X-ray photoelectron spectroscopy, nuclear magnetic resonance (NMR), X-ray diffraction analysis, X-ray absorption fine structure spectroscopy, scanning electron microscopy (SEM), and transmission electron microscopy (TEM), have been employed for identifying some active sites involved in binding of heavy metal ions [189, 201]. However, most studies employ Fourier-transform infrared spectroscopic (FT-IR) technique to identify and characterize certain functional groups present in microbial biomass for uptake of toxic heavy metals such as hexavalent chromium. FTIR 


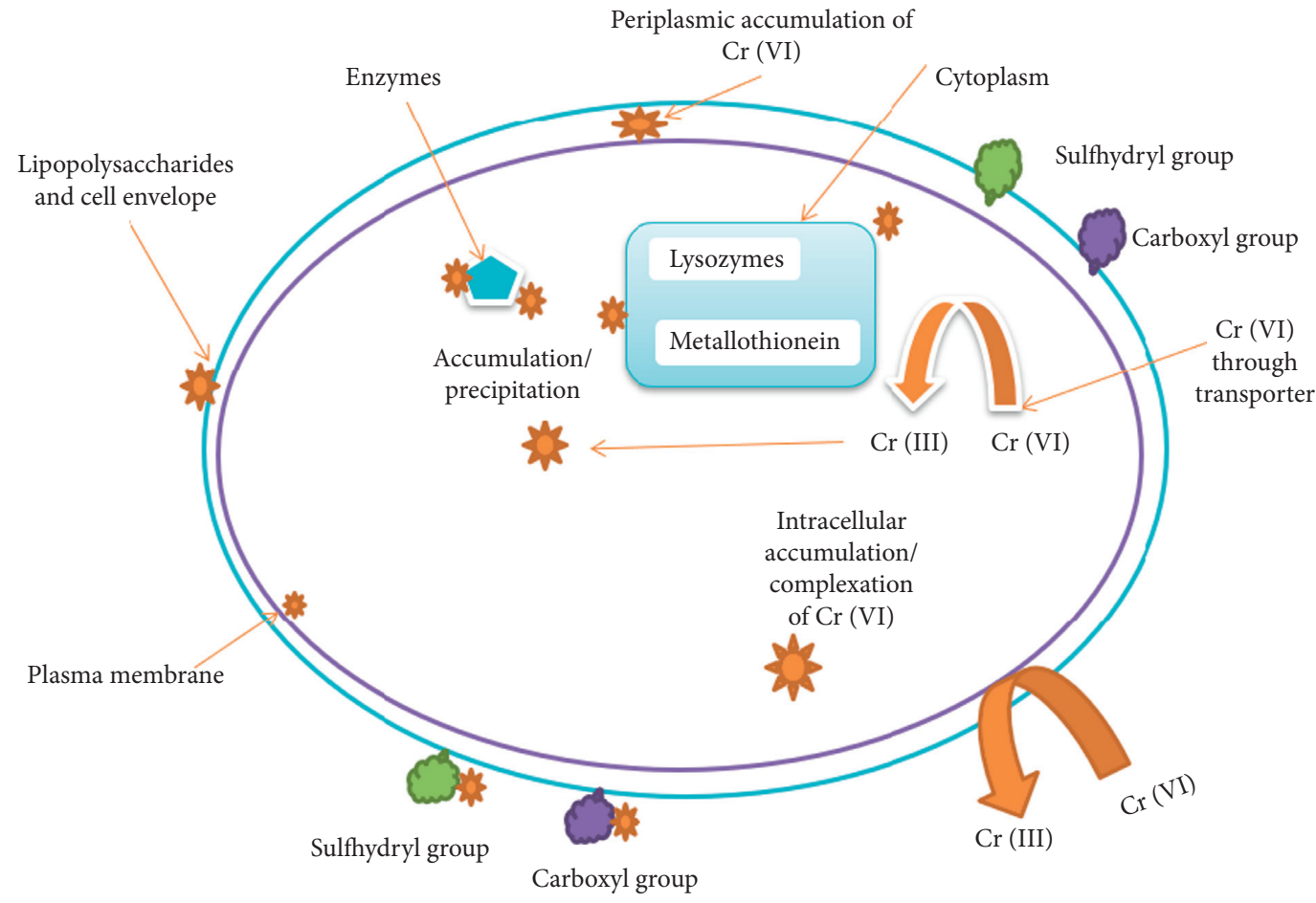

FIgURE 6: Mechanisms for Cr(VI) biosorption by microorganisms [88], [103].

TABLE 2: Involvement of various functional groups as revealed by FTIR analysis in chromium binding by different microorganisms.

\begin{tabular}{|c|c|c|c|c|}
\hline \multicolumn{5}{|c|}{ FUNGI } \\
\hline $\begin{array}{l}\text { S/ } \\
\text { no }\end{array}$ & Fungi & Functional groups & $\begin{array}{l}\text { Adsorption } \\
\text { isotherms }\end{array}$ & References \\
\hline 1 & Aspergillus foetidus & $\mathrm{C}=\mathrm{O}, \mathrm{C}-\mathrm{Cl}, \mathrm{PO}_{4}^{-3}$ amine, $\mathrm{N}=\mathrm{C}=\mathrm{S}, \mathrm{OH}, \mathrm{C}-\mathrm{O}$ & Freundlich & \multirow{8}{*}[190]{} \\
\hline 2 & Aspergillus niger & $\mathrm{C}=\mathrm{O}$, amine, $\mathrm{C}-\mathrm{OH}, \mathrm{C}-\mathrm{NH}_{3}$ & Freundlich & \\
\hline 3 & Aureobasidium pullulans & $\mathrm{C}=\mathrm{O}, \mathrm{C}-\mathrm{H}$, amine, $\mathrm{N}-\mathrm{N}=\mathrm{O}, \mathrm{C}=\mathrm{C}-\mathrm{H}$ & Freundlich & \\
\hline 4 & Aspergillus terricola & $\mathrm{C}=\mathrm{C}-\mathrm{H}, \mathrm{C}=\mathrm{O}, \mathrm{C}-\mathrm{OH}$, amine, $\mathrm{C}=\mathrm{N}$ & Freundlich & \\
\hline 5 & Cladosporium resinae & $\mathrm{C}=\mathrm{C}-\mathrm{H}, \mathrm{COH}, \mathrm{C}=\mathrm{C}-\mathrm{H} \mathrm{C}=\mathrm{C}, \mathrm{N}-\mathrm{N}=\mathrm{O}, \mathrm{CS}-\mathrm{NH}, \mathrm{C}=\mathrm{S}$ & Freundlich & \\
\hline 6 & Acremonium strictum & $\mathrm{C}=\mathrm{O}, \mathrm{CH}_{3}, \mathrm{C}-\mathrm{NH}_{3}, \mathrm{C}=\mathrm{C}-\mathrm{H}, \mathrm{C}-\mathrm{Cl}, \mathrm{C}=\mathrm{N}, \mathrm{C}-\mathrm{O}, \mathrm{COH}$ & Langmuir & \\
\hline 7 & Phanerochaete chrysosporium & $\mathrm{C}-\mathrm{O}, \mathrm{C}=\mathrm{C}, \mathrm{C}-\mathrm{Cl}$, amine, $\mathrm{C}=\mathrm{O}, \mathrm{C}=\mathrm{N}, \mathrm{CS}-\mathrm{NH}, \mathrm{PO}_{4}{ }^{-3}$ & Freundlich & \\
\hline 8 & Paecilomyces variotii & Amine, $\mathrm{CC}, \mathrm{CN}, \mathrm{OH}, \mathrm{PO}_{4}^{-3}, \mathrm{C}=\mathrm{S}, \mathrm{OH}$ & Langmuir & \\
\hline 9 & Aspergillus terreus & $-\mathrm{OH},-\mathrm{CH}, \mathrm{N}-\mathrm{H},-\mathrm{SO}_{2}-\mathrm{N}, \mathrm{P}-\mathrm{O}$ & - & {$[151]$} \\
\hline 10 & Pleurotus ostreatus & $\mathrm{NH}$ and $\mathrm{COOH}$ & - & [153] \\
\hline 11 & Aspergillus niger & $-\mathrm{COOH},-\mathrm{OH},-\mathrm{NH}_{2}$ & - & [187] \\
\hline 12 & Arthrinium malaysianum & $-\mathrm{OH}, \mathrm{C}-\mathrm{O}, \mathrm{C}=\mathrm{O},-\mathrm{NO}_{2}, \mathrm{C}_{\mathrm{x}} \mathrm{OH}$ & - & {$[191]$} \\
\hline \multicolumn{5}{|c|}{ BACTERIA } \\
\hline 1 & Bacillus marisflavi and Arthrobacter sp & $\begin{array}{l}\mathrm{OH},-\mathrm{NH} \text { acetamido group, amide bond, } \mathrm{C}=\mathrm{O} \text { of } \\
\mathrm{COO}-\text {, free phosphates, phosphate groups, }-\mathrm{CN}\end{array}$ & - & [192] \\
\hline 2 & Klebsiella sp. & $-\mathrm{NH} 2, \mathrm{O}-\mathrm{H},-\mathrm{CONH}-,-\mathrm{COOH}, \mathrm{C}=\mathrm{C},-\mathrm{CH}_{2}$ & Freundlich & [141] \\
\hline 3 & Halomonas sp. DK4 & $-\mathrm{OH},-\mathrm{CH}_{2}, \mathrm{~N}-\mathrm{H}, \mathrm{P}-\mathrm{O}-\mathrm{C}, \mathrm{C}=\mathrm{O}$ & Langmuir & {$[140]$} \\
\hline 4 & Bacillus cereus Pf- 1 & $\begin{array}{c}-\mathrm{OH},-\mathrm{CH} \text { and }-\mathrm{NH} \text { stretching, } \mathrm{C}=\mathrm{O},-\mathrm{COO}^{-},-\mathrm{C}-\mathrm{O} \\
\text { and }-\mathrm{C}-\mathrm{N}\end{array}$ & $\begin{array}{l}\text { Langmuir and } \\
\text { Freundlich }\end{array}$ & [193] \\
\hline 5 & Sinorhizobium sp. SAR1 & $\mathrm{N}-\mathrm{H}, \mathrm{O}-\mathrm{H}, \mathrm{C}-\mathrm{O}, \mathrm{P}-\mathrm{O}, \mathrm{C}-\mathrm{H}$ & Langmuir & {$[142]$} \\
\hline 6 & $\begin{array}{l}\text { Pseudomonas aeruginosa } \mathrm{Rb}-1 \text { and } \\
\text { Ochrobactrum intermedium } \mathrm{Rb}-2\end{array}$ & $\begin{aligned}-\mathrm{OH},-\mathrm{NH}, \mathrm{S}-\mathrm{H}, \mathrm{C}=\mathrm{C} \text {, carboxylic group, } \mathrm{SO}_{2} \mathrm{O}^{-}, \mathrm{C}-\mathrm{O}, \mathrm{S} \\
=\mathrm{O},-\mathrm{C}-\mathrm{C}-\text { and } \mathrm{C}-\mathrm{Cl},\end{aligned}$ & - & {$[194]$} \\
\hline 7 & Bacillus cereus IST105 & $\mathrm{O}-\mathrm{H}, \mathrm{N}-\mathrm{H}, \mathrm{C}=\mathrm{C}, \mathrm{P}=\mathrm{O}, \mathrm{C}-\mathrm{O}$ & - & [195] \\
\hline 8 & Streptomyces werraensis LD22 & $\mathrm{O}-\mathrm{H}$ or $\mathrm{N}-\mathrm{H}, \mathrm{C}-\mathrm{H}, \mathrm{C}-\mathrm{O}$ & - & [196] \\
\hline \multicolumn{5}{|c|}{ MICROALGAE } \\
\hline 1 & Spirulina platensis & $\begin{array}{c}\mathrm{C}=\mathrm{O}, \mathrm{C}-\mathrm{C}, \mathrm{C}-\mathrm{O}-\mathrm{C}, \mathrm{P}=\mathrm{O} \text { groups, } \mathrm{COO}-, \mathrm{CH}_{2} \text { and } \\
\mathrm{NHC}(\mathrm{O}) \text { amid groups, Carboxyl groups }\end{array}$ & - & {$[197]$} \\
\hline
\end{tabular}


TABLE 2: Continued.

\begin{tabular}{|c|c|c|c|c|}
\hline \multicolumn{5}{|c|}{ FUNGI } \\
\hline $\begin{array}{l}\text { S/ } \\
\text { no }\end{array}$ & Fungi & Functional groups & $\begin{array}{l}\text { Adsorption } \\
\text { isotherms }\end{array}$ & References \\
\hline 2 & Chlorella miniata & $\begin{array}{l}\text { Carboxylate group, } \mathrm{C}-\mathrm{O} \text {, amide } \mathrm{I} \text { and amide } \mathrm{II} \text {, amino } \\
\quad \text { group, } \mathrm{O}-\mathrm{H} \text { and } \mathrm{N}-\mathrm{H},-\mathrm{CH}_{3} \text { and } \\
>\mathrm{CH}_{2} \quad\end{array}$ & Langmuir & [198] \\
\hline 3 & Chlorella miniata & $\mathrm{O}-\mathrm{H}$ and $\mathrm{N}-\mathrm{H}, \mathrm{C}-\mathrm{H},-\mathrm{CH}_{3}, \mathrm{COO}-, \mathrm{P}=\mathrm{O}, \mathrm{C}-\mathrm{O}$ & - & [199] \\
\hline 4 & Spirulina platensis & $\begin{array}{c}-\mathrm{OH} \text { and }-\mathrm{NH}, \mathrm{C}=\mathrm{O},-\mathrm{C} \text { triple bond, } \mathrm{C}-\mathrm{H} \text {, carboxylate } \\
\text { and phosphoryl groups }\end{array}$ & Freundlich & {$[161]$} \\
\hline 5 & Isochrysis galbana, & $-\mathrm{OH},-\mathrm{COOH}$ and $\mathrm{C}=\mathrm{O},-\mathrm{NH}$ & $\begin{array}{l}\text { Langmuir and } \\
\text { Freundlich }\end{array}$ & {$[162]$} \\
\hline 6 & Pediastrum boryanum & $-\mathrm{OH},-\mathrm{COOH},-\mathrm{NH}, \mathrm{C}-\mathrm{O},-\mathrm{CH}_{3}, \mathrm{C}-\mathrm{OH}, \mathrm{C}-\mathrm{N}-\mathrm{C}$ & - & [174] \\
\hline 7 & Lyngbya putealis & $-\mathrm{NH},-\mathrm{CH},-\mathrm{C} \equiv \mathrm{N}$, and $-\mathrm{C}=\mathrm{C}$ & - & {$[200]$} \\
\hline 8 & Scenedesmus sp & $\mathrm{N}-\mathrm{H}, \mathrm{O}-\mathrm{H}, \mathrm{C}-\mathrm{H},-\mathrm{COOH}, \mathrm{C}-\mathrm{F}, \mathrm{C}-\mathrm{Cl}, \mathrm{C}-\mathrm{Br}, \mathrm{C}-\mathrm{O}$ & $\begin{array}{l}\text { Langmuir and } \\
\text { Freundlich }\end{array}$ & {$[167]$} \\
\hline
\end{tabular}

spectroscopy analysis was carried out to obtain the characteristics of the functional groups and to identify the chemical bonds that played a significant role in the process of biosorption of chromium [141].

As a whole, the functional groups associated with the cell wall significantly vary from microorganism to microorganisms. In addition, existence of different functional groups such as amine, amide, carbonyl, and phosphate together in microbial cell widens the intracellular accumulation and extracellular adsorption of toxic heavy metal ions. Therefore, functional groups play pivotal roles in the removal of heavy metal ions from the solution and the mechanism associated can also be determined after knowing certain functional group involved in biosorption.

\section{Conclusion}

This paper reviews chromium biosorption by various microorganisms such as bacteria, fungi, and microalgae, as well as factors that influence metal removal and sorption mechanisms. Microbial remediation of $\mathrm{Cr}(\mathrm{VI})$ from the environment is one of the most viable and sustainable methods for reducing excess $\mathrm{Cr}(\mathrm{VI})$ levels in the environment. These microbes have evolved impressive mechanisms to preserve their homeostasis and resistance to heavy metals to thrive in such a toxic environment. The biosorption process is a microorganism-based technology that is costeffective, safe, and simple to use for removing chromium from the water environment, and it has a lot of potential for future applications. Mechanisms involved in the biosorption process include transport across the cell membrane, complexation, ion exchange, precipitation, and physical adsorption. Metabolism-independent metal binding to the cell walls and external surfaces is the only mechanism present in the case of nonliving biomass. The biosorption capacity of biosorbents can be affected by the $\mathrm{pH}$ of the environment, temperature, contact time, biomass dosage, initial metal concentration, and other factors. Since, industrial wastewaters may contain more than one toxic heavy metal unlike laboratory solutions, simultaneous removal of many coexisting pollutants may be challenging. Hence, further research on these topics is needed to take full advantage of microbial biotechnology in environments. [201]

\section{Data Availability}

No data were used to support this study.

\section{Conflicts of Interest}

The authors declare they have no conflicts of interest.

\section{Acknowledgments}

The authors wish to acknowledge all who had been instrumental in the creation of this review article.

\section{References}

[1] H. Munjur, M. N. Hasan, M. R. Awual, M. M. Islam, M. A. Shenashen, and J. Iqbal, "Biodegradable natural carbohydrate polymeric sustainable adsorbents for efficient toxic dye removal from wastewater," Journal of Molecular Liquids, vol. 319, p. 114356, 2020.

[2] I. Ali, O. M. L. Alharbi, Z. A. ALOthman, A. Alwarthan, and A. M. Al-Mohaimeed, "Preparation of a carboxymethylcellulose-iron composite for uptake of atorvastatin in water," International Journal of Biological Macromolecules, vol. 132, pp. 244-253, 2019.

[3] M. Ismail, K. Akhtar, M. I. Khan et al., "Pollution, toxicity and carcinogenicity of organic dyes and their catalytic bioremediation," Current Pharmaceutical Design, vol. 25, no. 34, pp. 3645-3663, 2019.

[4] P. Chowdhary, A. Yadav, G. Kaithwas, and R. N. Bharagava, "Distillery wastewater: a major source of environmental pollution and its biological treatment for environmental safety," Green Technologies and Environmental Sustainability, pp. 409-435, 2017.

[5] S. Zainith, D. Purchase, G. D. Saratale, L. F. R. Ferreira, M. Bilal, and R. N. Bharagava, "Isolation and characterization of lignin-degrading bacterium Bacillus aryabhattai from pulp and paper mill wastewater and evaluation of its lignin-degrading potential," 3 Biotech, vol. 9, no. 3, p. 92, 2019. 
[6] P. Chowdhary, R. N. Bharagava, S. Mishra, and N. Khan, "Role of industries in water scarcity and its adverse effects on environment and human health," in Environmental Concerns and Sustainable Development, pp. 235-256, Springer, Berlin, Germany, 2020.

[7] Y. K. Leong and J.-S. Chang, "Bioremediation of heavy metals using microalgae: recent advances and mechanisms," Bioresource Technology, vol. 303, p. 122886, 2020.

[8] G. Pandey and S. Madhuri, "Heavy metals causing toxicity in animals and fishes," Research Journal of Animal, Veterinary and Fishery Sciences, vol. 2, no. 2, pp. 17-23, 2014.

[9] B. E. Igiri, S. I. R. Okoduwa, G. O. Idoko, E. P. Akabuogu, A. O. Adeyi, and I. K. Ejiogu, "Toxicity and bioremediation of heavy metals contaminated ecosystem from tannery wastewater: a review," Journal of Toxicology, vol. 2018, pp. 1-16, Article ID 2568038, 2018.

[10] M. U. Mustapha and N. Halimoon, "Microorganisms and biosorption of heavy metals in the environment: a review paper," Journal of Microbial and Biochemical Technology, vol. 7, no. 5, pp. 253-256, 2015.

[11] L. Sun, D. Guo, K. Liu et al., "Levels, sources, and spatial distribution of heavy metals in soils from a typical coal industrial city of Tangshan, China," Catena, vol. 175, pp. 101-109, 2019.

[12] J. He and J. P. Chen, "A comprehensive review on biosorption of heavy metals by algal biomass: materials, performances, chemistry, and modeling simulation tools," Bioresource Technology, vol. 160, pp. 67-78, 2014.

[13] G. A. Engwa, P. U. Ferdinand, F. N. Nwalo, and M. N. Unachukwu, "Mechanism and health effects of heavy metal toxicity in humans," Poisoning in the Modern World-New Tricks for an Old Dog, IntechOpen, vol. 10, London, UK, 2019.

[14] A. Asati, M. Pichhode, and K. Nikhil, "Effect of heavy metals on plants: an overview," International Journal of Application or Innovation in Engineering \& Management, vol. 5, no. 3, pp. 56-66, 2016.

[15] A. Ayangbenro and O. Babalola, "A new strategy for heavy metal polluted environments: a review of microbial biosorbents," International Journal of Environmental Research and Public Health, vol. 14, no. 1, p. 94, 2017.

[16] S. O. Owalude and A. C. Tella, "Removal of hexavalent chromium from aqueous solutions by adsorption on modified groundnut hull," Beni-Suef University Journal of Basic and Applied Sciences, vol. 5, no. 4, pp. 377-388, 2016.

[17] K. Choi, S. Lee, J. O. Park et al., "Chromium removal from aqueous solution by a PEI-silica nanocomposite," Scientific Reports, vol. 8, no. 1, pp. 1-10, 2018.

[18] H. Kumar, K. L. Maurya, A. K. Gehlaut et al., “Adsorptive removal of chromium(VI) from aqueous solution using binary bio-polymeric beads made from bagasse," Applied Water Science, vol. 10, no. 1, p. 21, 2019.

[19] A. Rahman, N. Nahar, N. N. Nawani et al., "Bioremediation of hexavalent chromium (VI) by a soil-borne bacterium,Enterobacter cloacaeB2-DHA," Journal of Environmental Science and Health, Part A, vol. 50, no. 11, pp. 1136-1147, 2015.

[20] M. Sen and M. G. Dastidar, "Chromium removal using various biosorbents," Journal of Environmental Health Science \& Engineering, vol. 7, no. 3, pp. 182-190, 2010.

[21] S. Bolisetty, M. Peydayesh, and R. Mezzenga, "Sustainable technologies for water purification from heavy metals: review and analysis," Chemical Society Reviews, vol. 48, no. 2, pp. 463-487, 2019.
[22] H. Abu Hasan, M. H. Muhammad, and N. I. Ismail, “A review of biological drinking water treatment technologies for contaminants removal from polluted water resources," Journal of Water Process Engineering, vol. 33, p. 101035, 2020.

[23] T. Shah and K. Saeed, "Experimental study on silver nanoparticles: synthesis, photo-degradation and analysis," Journal of Advances in Science and Engineering, vol. 3, no. 1, pp. 37-42, 2020.

[24] X. Liu, H. Pang, X. Liu et al., "Orderly porous covalent organic frameworks-based materials: superior adsorbents for pollutants removal from aqueous solutions," The Innovation, vol. 2, no. 1, p. 100076, 2021.

[25] L. Esrafili, F. D. Firuzabadi, A. Morsali, and M.-L. Hu, "Reuse of predesigned dual-functional metal organic frameworks (DF-MOFs) after heavy metal removal," Journal of Hazardous Materials, vol. 403, p. 123696, 2021.

[26] T. H. Tan, K. H. Mo, T.-C. Ling, and S. H. Lai, "Current development of geopolymer as alternative adsorbent for heavy metal removal," Environmental Technology \& Innovation, vol. 18, p. 100684, 2020.

[27] B. Qiu, X. Tao, H. Wang, W. Li, X. Ding, and H. Chu, "Biochar as a low-cost adsorbent for aqueous heavy metal removal: a review," Journal of Analytical and Applied Pyrolysis, vol. 155, p. 105081, 2021.

[28] U. Upadhyay, I. Sreedhar, S. A. Singh, C. M. Patel, and K. L. Anitha, "Recent advances in heavy metal removal by chitosan based adsorbents," Carbohydrate Polymers, vol. 251, p. $117000,2020$.

[29] M. Hasanpour and M. Hatami, "Application of three dimensional porous aerogels as adsorbent for removal of heavy metal ions from water/wastewater: a review study," Advances in Colloid and Interface Science, vol. 284, p. 102247, 2020.

[30] V. J. Landin-Sandoval, D. I. Mendoza-Castillo, A. BonillaPetriciolet, I. A. Aguayo-Villarreal, H. E. Reynel-Avila, and H. A. Gonzalez-Ponce, "Valorization of agri-food industry wastes to prepare adsorbents for heavy metal removal from water," Journal of Environmental Chemical Engineering, vol. 8, no. 5, p. 104067, 2020.

[31] S. Wadhawan, A. Jain, J. Nayyar, and S. K. Mehta, "Role of nanomaterials as adsorbents in heavy metal ion removal from waste water: a review," Journal of Water Process Engineering, vol. 33, p. 101038, 2020.

[32] O. Spain, M. Plöhn, and C. Funk, "The cell wall of green microalgae and its role in heavy metal removal," Physiologia Plantarum, 2021.

[33] Y. Zhu, X. He, J. Xu et al., "Insight into efficient removal of $\mathrm{Cr}(\mathrm{VI})$ by magnetite immobilized with Lysinibacillus sp. JLT12: mechanism and performance," Chemosphere, vol. 262, p. 127901, 2021.

[34] N. Subedi, A. Lähde, E. Abu-Danso, J. Iqbal, and A. Bhatnagar, "A comparative study of magnetic chitosan (Chi@Fe3O4) and graphene oxide modified magnetic chitosan (Chi@Fe3O4GO) nanocomposites for efficient removal of $\mathrm{Cr}(\mathrm{VI})$ from water," International Journal of Biological Macromolecules, vol. 137, pp. 948-959, 2019.

[35] L. P. Asha and R. S. Sandeep, "Review on bioremediationpotential tool for removing environmental pollution," International Journal of Basic and Applied Chemical Sciences, vol. 3, no. 3, pp. 21-33, 2013.

[36] F. Kafilzadeh and S. Saberifard, "Isolation and identification of chromium (VI)-resistant bacteria from Soltan Abad river sediments (Shiraz-Iran)," Jundishapur Journal of Health Sciences, vol. 8, no. 1, Article ID e33576, 2016. 
[37] T.-K. Tran, H.-J. Leu, K.-F. Chiu, and C.-Y. Lin, "Electrochemical treatment of heavy metal-containing wastewater with the removal of COD and heavy metal ions," Journal of the Chinese Chemical Society, vol. 64, no. 5, pp. 493-502, 2017.

[38] R. Chandra, S. Yadav, and S. Yadav, "Phytoextraction potential of heavy metals by native wetland plants growing on chlorolignin containing sludge of pulp and paper industry," Ecological Engineering, vol. 98, pp. 134-145, 2017.

[39] V. J. Joshi and D. D. Santani, "Physicochemical characterization and heavy metal concentration in effluent of textile industry," Universal Journal of Environmental Research \& Technology, vol. 2, no. 2, 2012.

[40] L. Angelovičová and D. Fazekašová, "Contamination of the soil and water environment by heavy metals in the former mining area of Rudňany (Slovakia)," Soil and Water Research, vol. 9, no. 1, pp. 18-24, 2014.

[41] C. Das, K. Naseera, A. Ram, R. M. Meena, and N. Ramaiah, "Bioremediation of tannery wastewater by a salt-tolerant strain of Chlorella vulgaris," Journal of Applied Phycology, vol. 29, no. 1, pp. 235-243, 2016.

[42] M. S. Islam, M. K. Ahmed, M. Raknuzzaman, M. Habibullah -Al- Mamun, and M. K. Islam, "Heavy metal pollution in surface water and sediment: a preliminary assessment of an urban river in a developing country," Ecological Indicators, vol. 48, pp. 282-291, 2015.

[43] S. Aslam and A. M. Yousafzai, "Chromium toxicity in fish: a review article," Journal of Entomology and Zoology Studies, vol. 5, no. 3, pp. 1483-1488, 2017.

[44] B.-D. Elena-Suzana, M. Tofana, T. Mihaiescu, and A. Odagiu, "Applications of microalgae in wastewater treatments: a review," ProEnvironment, vol. 9, pp. 459-463, 2016.

[45] K. Mohammed and O. Sahu, "Bioadsorption and membrane technology for reduction and recovery of chromium from tannery industry wastewater," Environmental Technology \& Innovation, vol. 4, pp. 150-158, 2015.

[46] H. Nigam, M. Das, S. Chauhan et al., "Effect of chromium generated by solid waste of tannery and microbial degradation of chromium to reduce its toxicity: a review," Advances in Applied Science Research, vol. 6, no. 3, pp. 129-136, 2015.

[47] K. Shekhawat, S. Chatterjee, and B. Joshi, "Chromium toxicity and its health hazards," International Journal of Advanced Research, vol. 3, no. 7, pp. 167-172, 2015.

[48] F. H. Were, M. C. Moturi, and G. A. Wafula, "Chromium exposure and related health effects among tannery workers in Kenya," Journal of Health and Pollution, vol. 4, no. 7, pp. 25-35, 2014.

[49] L. S. McNeill, J. E. McLean, J. L. Parks, and M. A. Edwards, "Hexavalent chromium review, part 2: chemistry, occurrence, and treatment," Journal - American Water Works Association, vol. 104, no. 7, pp. E395-E405, 2012.

[50] M. Shahid, S. Shamshad, M. Rafiq et al., "Chromium speciation, bioavailability, uptake, toxicity and detoxification in soil-plant system: a review," Chemosphere, vol. 178, pp. 513-533, 2017.

[51] B.J. Alloway, Heavy Metals in Soils: Trace Metals and Metalloids in Soils and their Bioavailability, Springer, Berlin, Germany, 2013.

[52] M. B. Arain, I. Ali, E. Yilmaz, and M. Soylak, "Nanomaterial's based chromium speciation in environmental samples: a review," TrAC Trends in Analytical Chemistry, vol. 103, pp. 44-55, 2018.
[53] M. Monalisa and P. H. Kumar, "Effect of ionic and chelate assisted hexavalent chromium on mung bean seedlings (Vigna radiata L. wilczek. var k-851) during seedling growth," Journal of Stress Physiology \& Biochemistry, vol. 9, no. 2, pp. 232-241, 2013.

[54] H. Sun, J. Brocato, and M. Costa, "Oral chromium exposure and toxicity," Current Environmental Health Reports, vol. 2, no. 3, pp. 295-303, 2015.

[55] T. B. Asfaw, T. M. Tadesse, and A. M. Ewnetie, "Determination of total chromium and chromium species in kombolcha tannery wastewater, surrounding soil, and lettuce plant samples, south wollo, Ethiopia," Advances in Chemistry, vol. 1, p. 7, 2017.

[56] D. Pradhan, L. B. Sukla, M. Sawyer, and P. K. S. M. Rahman, "Recent bioreduction of hexavalent chromium in wastewater treatment: a review," Journal of Industrial and Engineering Chemistry, vol. 55, pp. 1-20, 2017.

[57] H. Al-Battashi, S. J. Joshi, B. Pracejus, and A. Al-Ansari, "The geomicrobiology of chromium (VI) pollution: microbial diversity and its bioremediation potential," The Open Biotechnology Journal, vol. 10, no. 1, pp. 379-389, 2016.

[58] L. Escudero-Castejon, S. Sanchez-Segado, S. Parirenyatwa, and A. Jha, "Formation of chromium-containing molten salt phase during roasting of chromite ore with sodium and potassium hydroxides," Journal for Manufacturing Science and Production, vol. 16, pp. 215-225, 2016.

[59] S. K. Haldar, "Introduction," in Platinum-Nickel-Chromium Deposits, pp. 1-35, Elsevier, Amsterdam, Netherlands, 2017.

[60] M. Tumolo, V. Ancona, D. De Paola et al., "Chromium pollution in European water, sources, health risk, and remediation strategies: an overview," International Journal of Environmental Research and Public Health, vol. 17, no. 15, p. 5438,2020 .

[61] S. Mishra and R. N. Bharagava, "Toxic and genotoxic effects of hexavalent chromium in environment and its bioremediation strategies," Journal of Environmental Science and Health, Part C, vol. 34, no. 1, pp. 1-32, 2015.

[62] R. Jobby, P. Jha, A. K. Yadav, and N. Desai, "Biosorption and biotransformation of hexavalent chromium [Cr(VI)]: a comprehensive review," Chemosphere, vol. 207, pp. 255-266, 2018.

[63] H.-W. Yen, P.-W. Chen, C.-Y. Hsu, and L. Lee, "The use of autotrophic Chlorella Vulgaris in chromium (VI) reduction under different reduction conditions," Journal of the Taiwan Institute of Chemical Engineers, vol. 74, pp. 1-6, 2017.

[64] C. F. Carolin, P. S. Kumar, A. Saravanan, G. J. Joshiba, and M. Naushad, "Efficient techniques for the removal of toxic heavy metals from aquatic environment: a review," Journal of Environmental Chemical Engineering, vol. 5, no. 3, pp. 2782-2799, 2017.

[65] M. Jaishankar, T. Tseten, N. Anbalagan, B. B. Mathew, and K. N. Beeregowda, "Toxicity, mechanism and health effects of some heavy metals," Interdisciplinary Toxicology, vol. 7, no. 2, pp. 60-72, 2014.

[66] S. P. Kamaludeen, M. Megharaj, A. L. Juhasz, N. Sethunathan, and R. Naidu, "Chromium-microorganism interactions in soils: remediation implications," in Reviews of Environmental Contamination and Toxicology, G. W. Ware, Ed., vol. 178, Berlin, Germany, Springer, 2003.

[67] P. A. Kobielska, A. J. Howarth, O. K. Farha, and S. Nayak, "Metal-organic frameworks for heavy metal removal from water," Coordination Chemistry Reviews, vol. 358, pp. 92107, 2018. 
[68] D. Paul, "Research on heavy metal pollution of river Ganga: a review," Annals of Agrarian Science, vol. 15, no. 2, pp. 278-286, 2017.

[69] P. P. Tripathi and J. H. Sumathy, "A comparative study on the application of algae for bioremediation of cooum water," International Journal of Engineering and Techniques, vol. 4, pp. 2395-1303, 2018.

[70] A. A. Al-homaidan, H. S. Al-qahtani, A. A. Al-ghanayem, F. Ameen, and I. B. M. Ibraheem, "Potential use of green algae as a biosorbent for hexavalent chromium removal from aqueous solutions," Saudi Journal of Biological Sciences, vol. 25, no. 8, pp. 1733-1738, 2018.

[71] H.-J. Lunk, "Discovery, properties and applications of chromium and its compounds," ChemTexts, vol. 1, no. 1, 2015.

[72] N. Unceta, F. Séby, J. Malherbe, and O. F. X. Donard, "Chromium speciation in solid matrices and regulation: a review," Analytical and Bioanalytical Chemistry, vol. 397, no. 3, pp. 1097-1111, 2010.

[73] A. Pizent, B. Tariba, and T. Živković, "Reproductive toxicity of metals InMen," Archives of Industrial Hygiene and Toxicology, vol. 63, no. 1, pp. 35-46, 2012.

[74] T. A, "Physiological effect of chromium exposure: a review," International Journal of Food Science, Nutrition and Dietetics, vol. 7, pp. 1-11, 2016.

[75] L. Anah and N. Astrini, "Influence of $\mathrm{pH}$ on $\mathrm{Cr}(\mathrm{VI})$ ions removal from aqueous solutions using carboxymethyl cellulose-based hydrogel as adsorbent," IOP Conference Series: Earth and Environmental Science, vol. 60, p. 012010, 2017.

[76] B. Leśniewska, A. Jeglikowska, and B. GodlewskaŻyłkiewicz, "Chromium speciation in wastewater and sewage by solid-phase extraction using a new diphenylcarbazone-incorporated resin," Water, Air, \& Soil Pollution, vol. 227, no. 8, p. 291, 2016.

[77] S. H. Abbas, I. M. Ismail, T. M. Mostafa, and A. H. Sulaymon, "Biosorption of heavy Metals : a review," Journal of Chemical Science and Technology, vol. 3, pp. 74-102, 2014.

[78] P. Sahoo, K. B. Satapathy, and C. R. Panda, "Toxicity of chromium and its green remedies," International Journal of Research in Advent Technology, vol. 6, pp. 2686-2690, 2018.

[79] B. Markiewicz, I. Komorowicz, A. Sajnóg, M. Belter, and D. Barałkiewicz, "Chromium and its speciation in water samples by HPLC/ICP-MS - technique establishing metrological traceability: a review since 2000," Talanta, vol. 132, pp. 814-828, 2015.

[80] F. Minas, B. S. Chandravanshi, and S. Leta, "Chemical precipitation method for chromium removal and its recovery from tannery wastewater in Ethiopia," Chemistry International, vol. 3, pp. 392-405, 2017.

[81] M. Shadreck and T. Mugadza, "Chromium, an essential nutrient and pollutant: a review," African Journal of Pure and Applied Chemistry, vol. 7, no. 9, pp. 310-317, 2013.

[82] H. Oliveira, "Chromium as an environmental pollutant: insights on induced plant toxicity," Journal of Botany, vol. 2012, Article ID 375843, 8 pages, 2012.

[83] R. Achmad, E. I. Budiawan, and E. Auerkari, "Effects of chromium on human body," Annual Research \& Review in Biology, vol. 13, no. 2, pp. 1-8, 2017.

[84] S. Lewicki, R. Zdanowski, M. Krzyzowska et al., "The role of Chromium III in the organism and its possible use in diabetes and obesity treatment," Annals of Agricultural and Environmental Medicine, vol. 21, no. 2, 2014.

[85] A. Elahi, I. Arooj, D. A. Bukhari, and A. Rehman, "Successive use of microorganisms to remove chromium from wastewater," Applied Microbiology and Biotechnology, vol. 104, no. 9, pp. 3729-3743, 2020.

[86] D. J. McIver, A. M. Grizales, J. S. Brownstein, and A. B. Goldfine, "Risk of type 2 diabetes is lower in US adults taking chromium-containing supplements," The Journal of Nutrition, vol. 145, no. 12, pp. 2675-2682, 2015.

[87] W. Yang, W. Song, J. Li, and X. Zhang, "Bioleaching of heavy metals from wastewater sludge with the aim of land application," Chemosphere, vol. 249, p. 126134, 2020.

[88] A. Bhattacharya, A. Gupta, A. Kaur, and D. Malik, "Alleviation of hexavalent chromium by using microorganisms: insight into the strategies and complications," Water Science and Technology, vol. 79, no. 3, pp. 411-424, 2019.

[89] T. L. DesMarias and M. Costa, "Mechanisms of chromiuminduced toxicity," Current Opinion in Toxicology, vol. 14, pp. 1-7, 2019.

[90] F. Vendruscolo, G. L. da Rocha Ferreira, N. R. Antoniosi Filho, and A. Filho, "Biosorption of hexavalent chromium by microorganisms," International Biodeterioration \& Biodegradation, vol. 119, pp. 87-95, 2017.

[91] Z. Chen, S. Song, and Y. Wen, "Reduction of Cr (VI) into Cr (III) by organelles of Chlorella vulgaris in aqueous solution: an organelle-level attempt," Science of the Total Environment, vol. 572, pp. 361-368, 2016.

[92] P. M. Fernández, S. C. Viñarta, A. R. Bernal, E. L. Cruz, and L. I. C. Figueroa, "Bioremediation strategies for chromium removal: current research, scale-up approach and future perspectives," Chemosphere, vol. 208, pp. 139-148, 2018.

[93] A. Esmaeili, S. Ghasemi, and A. Rustaiyan, "Removal of hexavalent chromium using activated carbons derived from marine algae gracllaria and sargassum sp," Journal of Marine Science and Technology, vol. 18, pp. 587-592, 2010.

[94] M. Junaid, M. Z. Hashmi, R. N. Malik, and D.-S. Pei, "Toxicity and oxidative stress induced by chromium in workers exposed from different occupational settings around the globe: a review," Environmental Science and Pollution Research, vol. 23, no. 20, pp. 20151-20167, 2016.

[95] A. Seidler, S. Jähnichen, J. Hegewald et al., "Systematic review and quantification of respiratory cancer risk for occupational exposure to hexavalent chromium," International Archives of Occupational and Environmental Health, vol. 86, no. 8, pp. 943-955, 2013.

[96] S. Focardi, M. Pepi, and E. S. Focardi, "Microbial reduction of hexavalent chromium as a mechanism of detoxification and possible bioremediation applications," Biodegradation Life of Science, 2013.

[97] R. Shrivastava, R. K. Upreti, P. K. Seth, and U. C. Chaturvedi, "Effects of chromium on the immune system," FEMS Immunology \& Medical Microbiology, vol. 34, no. 1, pp. 1-7, 2002.

[98] F. Yang and I. Y. Massey, "Exposure routes and health effects of heavy metals on children," Biometals, vol. 32, no. 4, pp. 563-573, 2019.

[99] S. Wilbur, M. Williams, R. Williams et al., Toxicological Profile for Carbon Monoxide, 2013.

[100] C. Cervantes, J. Campos-García, S. Devars et al., "Interactions of chromium with microorganisms and plants," FEMS Microbiology Reviews, vol. 25, no. 3, pp. 335-347, 2001.

[101] A. Shanker, C. Cervantes, H. Lozatavera, and S. Avudainayagam, "Chromium toxicity in plants," Environment International, vol. 31, no. 5, pp. 739-753, 2005.

[102] U. Y. Stambulska, M. M. Bayliak, and V. I. Lushchak, "Chromium(VI) toxicity in legume plants: modulation 
effects of rhizobial symbiosis," BioMed Research International, vol. 2018, pp. 1-13, Article ID 8031213, 2018.

[103] S. Guo, C. Xiao, N. Zhou, and R. Chi, "Speciation, toxicity, microbial remediation and phytoremediation of soil chromium contamination," Environmental Chemistry Letters, pp. 1-19, 2020.

[104] Z. ALOthman, "A review: fundamental aspects of silicate mesoporous materials," Materials, vol. 5, no. 12, pp. 2874-2902, 2012.

[105] A. A. Alqadami, M. Naushad, Z. A. ALOthman, M. Alsuhybani, and M. Algamdi, "Excellent adsorptive performance of a new nanocomposite for removal of toxic $\mathrm{Pb}$ (II) from aqueous environment: adsorption mechanism and modeling analysis," Journal of Hazardous Materials, vol. 389, p. 121896, 2020.

[106] M. A. Khan, A. A. Alqadami, S. M. Wabaidur et al., "Oil industry waste based non-magnetic and magnetic hydrochar to sequester potentially toxic post-transition metal ions from water," Journal of Hazardous Materials, vol. 400, p. 123247 , 2020.

[107] R. Shahbazi and M. Z. Pedram, "Continuous photocatalytic set-up assisted with nano TiO2 plate for tannery wastewater treatment," Water Science and Technology, vol. 83, no. 11, pp. 2732-2743, 2021.

[108] E. Daneshvar, M. J. Zarrinmehr, M. Kousha et al., "Hexavalent chromium removal from water by microalgal-based materials: adsorption, desorption and recovery studies," Bioresource Technology, vol. 293, p. 122064, 2019.

[109] S. L. R. K. Kanamarlapudi, V. K. Chintalpudi, and S. Muddada, "Application of biosorption for removal of heavy metals from wastewater," Biosorption, vol. 18, pp. 69-116, 2018.

[110] R. Pun, P. Raut, and B. R. Pant, "Removal of chromium (VI) from leachate using bacterial biomass," Scientific World, vol. 11, no. 11, pp. 63-65, 2013.

[111] N. A. Renu, M. Agarwal, and K. Singh, "Methodologies for removal of heavy metal ions from wastewater: an overview," Interdisciplinary Environmental Review, vol. 18, no. 2, pp. 124-142, 2017.

[112] M. Sutkowy and G. Kłosowski, "Use of the coenobial green algae pseudopediastrum boryanum (chlorophyceae) to remove hexavalent chromium from contaminated aquatic ecosystems and industrial wastewaters," Water, vol. 10, no. 6, p. 712, 2018.

[113] W. Tariq, M. Saifullah, T. Anjum, M. Javed, N. Tayyab, and I. Shoukat, "Removal of heavy metals from chemical industrial wastewater using agro-based bio-sorbents," Acta Chemica Malaysia, vol. 2, pp. 9-14, 2018.

[114] M. Wołowiec, M. Komorowska-Kaufman, A. Pruss, G. Rzepa, and T. Bajda, "Removal of heavy metals and metalloids from water using drinking water treatment residuals as adsorbents: a review," Minerals, vol. 9, p. 487, 2019.

[115] Y.-L. Chen, X.-Q. Hong, H. He et al., "Biosorption of Cr (VI) by Typha angustifolia: mechanism and responses to heavy metal stress," Bioresource Technology, vol. 160, pp. 89-92, 2014.

[116] S. A. Sadeek, N. A. Negm, H. H. H. Hefni, and M. M. A. Wahab, "Metal adsorption by agricultural biosorbents: adsorption isotherm, kinetic and biosorbents chemical structures," International Journal of Biological Macromolecules, vol. 81, pp. 400-409, 2015.

[117] P. Kanmani, J. Aravind, and D. Preston, "Remediation of chromium contaminants using bacteria," International
Journal of Environmental Science and Technology, vol. 9, no. 1, pp. 183-193, 2012.

[118] P. Diep, R. Mahadevan, and A. F. Yakunin, "Heavy metal removal by bioaccumulation using genetically engineered microorganisms," Frontiers in Bioengineering and Biotechnology, vol. 6, p. 157, 2018.

[119] T. Kikuchi and S. Tanaka, "Biological removal and recovery of toxic heavy metals in water environment," Critical Reviews in Environmental Science and Technology, vol. 42, no. 10, pp. 1007-1057, 2012.

[120] K. GracePavithra, V. Jaikumar, P. S. Kumar, and P. SundarRajan, "A review on cleaner strategies for chromium industrial wastewater: present research and future perspective," Journal of Cleaner Production, vol. 228, pp. 580-593, 2019.

[121] M. Bilal, T. Rasheed, J. Sosa-Hernández, A. Raza, F. Nabeel, and H. Iqbal, "Biosorption: an interplay between marine algae and potentially toxic elements-A review," Marine Drugs, vol. 16, no. 2, p. 65, 2018.

[122] A. Ghavidel, S. Naji Rad, H. A. Alikhani, M. Sharari, and A. Ghanbari, "Bioleaching of heavy metals from sewage sludge, direct action of Acidithiobacillus ferrooxidans or only the impact of $\mathrm{pH}$ ?," Journal of Material Cycles and Waste Management, vol. 20, no. 2, pp. 1179-1187, 2018.

[123] X. Y. Gu, J. W. C. Wong, and R. D. Tyagi, "Bioleaching of heavy metals from sewage sludge for land application," in Current Developments in Biotechnology and Bioengineering, pp. 241-265, Elsevier, Amsterdam, Netherlands, 2017.

[124] L. Lee, C.-Y. Hsu, and H.-W. Yen, "The effects of hydraulic retention time (HRT) on chromium(VI) reduction using autotrophic cultivation of Chlorella vulgaris," Bioprocess and Biosystems Engineering, vol. 40, no. 12, pp. 1725-1731, 2017.

[125] M. K. Gagrai, C. Das, and A. K. Golder, "Reduction of Cr(VI) into $\mathrm{Cr}(\mathrm{III})$ by Spirulina dead biomass in aqueous solution: kinetic studies," Chemosphere, vol. 93, no. 7, pp. 1366-1371, 2013.

[126] B. Dhir, "Potential of biological materials for removing heavy metals from wastewater," Environmental Science and Pollution Research, vol. 21, no. 3, pp. 1614-1627, 2014.

[127] H. Rezaei, "Biosorption of chromium by using Spirulina sp," Arabian Journal of Chemistry, vol. 9, no. 6, pp. 846-853, 2016.

[128] B. Buszewski, E. Dziubakiewicz, P. Pomastowski et al., "Assignment of functional groups in Gram-positive bacteria," Journal of Analytical \& Bioanalytical Techniques, vol. 6, no. 1, p. 1, 2015.

[129] R. Garcia-Rubio, H. C. de Oliveira, J. Rivera, and N. Trevijano-Contador, "The fungal cell wall: Candida, Cryptococcus, and Aspergillus species," Frontiers in $\mathrm{Mi}$ crobiology, vol. 10, p. 2993, 2020.

[130] A. Synytsya, J. Čopíková, W. J. Kim, and Y. I. Park, "Cell wall polysaccharides of marine algae," in Springer Handbook of Marine Biotechnology, S. K. Kim, Ed., Springer Handbooks. Springer, Berlin, Germany, 2015.

[131] K. Chojnacka, "Biosorption and bioaccumulation - the prospects for practical applications," Environment International, vol. 36, no. 3, pp. 299-307, 2010.

[132] U. Farooq, J. A. Kozinski, M. A. Khan, and M. Athar, "Biosorption of heavy metal ions using wheat based biosorbents - a review of the recent literature," Bioresource Technology, vol. 101, no. 14, pp. 5043-5053, 2010.

[133] W.-W. Li and H.-Q. Yu, "Insight into the roles of microbial extracellular polymer substances in metal biosorption," Bioresource Technology, vol. 160, pp. 15-23, 2014. 
[134] A. Dadrasnia, K. Chuan Wei, N. Shahsavari, M. Azirun, and S. Ismail, "Biosorption potential of Bacillus salmalaya strain 139SI for removal of $\mathrm{Cr}(\mathrm{VI})$ from aqueous solution," International Journal of Environmental Research and Public Health, vol. 12, no. 12, pp. 15321-15338, 2015.

[135] N. Upadhyay, K. Vishwakarma, J. Singh et al., "Tolerance and reduction of chromium (VI) by Bacillus sp. MNU16 isolated from contaminated coal mining soil," Frontiers in Plant Science, vol. 8, 2017.

[136] H. Li, S. Huang, and Y. Zhang, "Cr(VI) removal from aqueous solution by thermophilic denitrifying bacterium Chelatococcus daeguensis TAD1 in the presence of single and multiple heavy metals," Journal of Microbiology, vol. 54, no. 9, pp. 602-610, 2016.

[137] S. Congeevaram, S. Dhanarani, J. Park, M. Dexilin, and K. Thamaraiselvi, "Biosorption of chromium and nickel by heavy metal resistant fungal and bacterial isolates," Journal of Hazardous Materials, vol. 146, no. 1-2, pp. 270-277, 2007.

[138] S. Subramanian, M. Pulimi, and G. Jayaraman, "Statistical optimization on chromium (VI) reduction by marine bacteria, planococcus sp. VITP21 using cane sugar as carbon source," International Journal of Chemical Sciences, vol. 12, no. 1, pp. 169-180, 2014.

[139] N. E.-A. El-Naggar, A. Y. El-khateeb, A. A. Ghoniem, M. S. El-Hersh, and W. I. A. Saber, "Innovative low-cost biosorption process of Cr6+ by Pseudomonas alcaliphila NEWG-2," Scientific Reports, vol. 10, no. 1, 2020.

[140] V. Kalola and C. Desai, "Biosorption of $\mathrm{Cr}(\mathrm{VI})$ by Halomonas sp. DK4, a halotolerant bacterium isolated from chrome electroplating sludge," Environmental Science and Pollution Research, 2019.

[141] S. Hossan, S. Hossain, M. R. Islam et al., "Bioremediation of hexavalent chromium by chromium resistant bacteria reduces phytotoxicity," International Journal of Environmental Research and Public Health, vol. 17, no. 17, p. 6013, 2020.

[142] R. Jobby, P. Jha, A. Gupta, A. Gupte, and N. Desai, "Biotransformation of chromium by root nodule bacteria Sinorhizobium sp. SAR1," PLoS One, vol. 14, no. 7, Article ID e0219387, 2019.

[143] S. Sharma and P. Malaviya, "Bioremediation of tannery wastewater by chromium resistant novel fungal consortium," Ecological Engineering, vol. 91, pp. 419-425, 2016.

[144] M. K. Guria, A. K. Guha, and M. Bhattacharyya, "A green chemical approach for biotransformation of $\mathrm{Cr}(\mathrm{VI})$ to $\mathrm{Cr}(\mathrm{III})$, utilizing Fusarium sp. MMT1 and consequent structural alteration of cell morphology," Journal of Environmental Chemical Engineering, vol. 2, no. 1, pp. 424-433, 2014.

[145] D. Sivakumar, "Biosorption of hexavalent chromium in a tannery industry wastewater using fungi species," Global Journal of Environmental Science and Management, vol. 2, no. 2, p. 105, 2016.

[146] A. Mishra and A. Malik, "Novel fungal consortium for bioremediation of metals and dyes from mixed waste stream," Bioresource Technology, vol. 171, pp. 217-226, 2014.

[147] B. E. Ta, stan, S. Ertugrul, and G. Dönmez, "Effective bioremoval of reactive dye and heavy metals by Aspergillus versicolor," Bioresource Technology, vol. 101, pp. 870-876, 2010.

[148] M. Sukumar, "Reduction of hexavalent chromium by rhizopus oryzae," African Journal of Environmental Science and Technology, vol. 4, pp. 412-418, 2010.

[149] M. T. Garza-González, J. E. Ramírez-Vázquez, M. d. l. Á García-Hernández, M. E. Cantú-Cárdenas,
A. Liñan-Montes, and J. F. Villarreal-Chiu, "Reduction of chromium (VI) from aqueous solution by biomass of Cladosporium cladosporioides," Water Science and Technology, vol. 76, no. 9, pp. 2494-2502, 2017.

[150] J. R. M. Benila Smily and P. A. Sumithra, "Optimization of chromium biosorption by fungal adsorbent, Trichoderma sp. BSCR02 and its desorption studies," HAYATI Journal of Biosciences, vol. 24, no. 2, pp. 65-71, 2017.

[151] M. D. B. Kumaran, M. Prasathkum, D. J. M. Kumar, and P. T. Kalaichelv, "Utilization of Aspergillus terreus for the biosorption of hexavalent chromium ions," Asian Journal of Biological Sciences, vol. 6, no. 7, pp. 312-321, 2013.

[152] G. L. da Rocha Ferreira, F. Vendruscolo, and N. R. Antoniosi Filho, "Biosorption of hexavalent chromium by Pleurotus ostreatus," Heliyon, vol. 5, no. 3, p. e01450, 2019.

[153] M. Arbanah, N. M. R. Miradatul, and K. K. H. Halim, "Utilization of Pleurotus ostreatus in the removal of $\mathrm{Cr}$ (VI) from chemical laboratory waste," International Refereed Journal of Engineering and Science, vol. 2, no. 4, pp. 29-39, 2013.

[154] D. Pradhan, N. Devi, and L. B. Sukla, "Biosorption of hexavalent chromium using biomass of microalgae scenedesmus SP," International Journal of Engineering \& Technology, vol. 7, no. 3, pp. 558-563, 2018.

[155] T. S. Dao, N.-H.-S. Le, M.-T. Vo, T.-M.-C. Vo, and T.-H. Phan, "Growth and metal uptake capacity of microalgae under exposure to chromium," Journal of Vietnamese Environment, vol. 9, no. 1, pp. 38-43, 2018.

[156] M. Ballen Segura, L. Hernandez Rodriguez, D. Parra Ospina, A. Vega Bolaños, and K. Pérez, "Using scenedesmus sp. for the phycoremediation of tannery wastewater," TECCIENCIA, vol. 11, no. 21, pp. 69-75, 2016.

[157] J. Jaafari and K. Yaghmaeian, "Optimization of heavy metal biosorption onto freshwater algae (Chlorella coloniales) using response surface methodology (RSM)," Chemosphere, vol. 217, pp. 447-455, 2019.

[158] S. Husien, A. Labena, E. F. El-Belely, H. M. Mahmoud, and A. S. Hamouda, "Absorption of hexavalent chromium by green micro algae Chlorella sorokiniana: live planktonic cells," Water Practice and Technology, vol. 14, 2019.

[159] R. M. Kumar, J. Frankilin, and S. P. Raj, "Accumulation of heavy metals $(\mathrm{Cu}, \mathrm{Cr}, \mathrm{Pb}$ and $\mathrm{Cd})$ in freshwater micro algae (Chlorella sp.)," Journal of Environmental Science \& Engineering, vol. 55, no. 3, pp. 371-376, 2013.

[160] P. Indhumathi, P. S. Syed Shabudeen, U. S. Shoba, and C. P. Saraswathy, "The removal of chromium from aqueous solution by using green micro algae," Journal of Chemical and Pharmaceutical Research, vol. 6, no. 6, pp. 799-808, 2014.

[161] K. Nithya, A. Sathish, K. Pradeep, and S. Kiran Baalaji, “Algal biomass waste residues of Spirulina platensis for chromium adsorption and modeling studies," Journal of Environmental Chemical Engineering, vol. 7, no. 5, p. 103273, 2019.

[162] K. K. Kadimpati, K. P. Mondithoka, S. Bheemaraju, and V. R. M. Challa, "Entrapment of marine microalga, Isochrysis galbana, for biosorption of $\mathrm{Cr}$ (III) from aqueous solution: isotherms and spectroscopic characterization," Applied Water Science, vol. 3, no. 1, pp. 85-92, 2013.

[163] A. Ayele, A. Suresh, S. Benor, and R. Konwarh, "Optimization of chromium (VI) removal by indigenous microalga (Chlamydomonas sp.) based biosorbent using response surface methodology," Water Environment Research: a Research Publication of the Water Environment Federation, 2021. 
[164] H. Thatoi, S. Das, J. Mishra, B. P. Rath, and N. Das, "Bacterial chromate reductase, a potential enzyme for bioremediation of hexavalent chromium: a review," Journal of Environmental Management, vol. 146, pp. 383-399, 2014.

[165] I. Zinicovscaia, "A review of biosorption of chromium ions by microorganisms," Chemistry Journal of Moldova, vol. 7, no. 2, pp. 27-31, 2012.

[166] M. A. García-Hernández, J. F. Villarreal-Chiu, and M. T. Garza-González, "Metallophilic fungi research: an alternative for its use in the bioremediation of hexavalent chromium," International Journal of Environmental Science and Technology, vol. 14, no. 9, pp. 2023-2038, 2017.

[167] D. Pradhan, L. B. Sukla, B. B. Mishra, and N. Devi, "Biosorption for removal of hexavalent chromium using microalgae Scenedesmus sp," Journal of Cleaner Production, vol. 209, pp. 617-629, 2019.

[168] J. Derco and B. Vrana, "Introductory Chapter: Biosorption," in Biosorption, pp. 1-19, IntechOpen, London, UK, 2018.

[169] W. S. Chai, W. G. Tan, H. S. H. Munawaroh, V. K. Gupta, S. H. Ho, and P. L. Show, "Multifaceted roles of microalgae in the application of wastewater biotreatment: a review," Environmental Pollution, vol. 269, 2020.

[170] K. Nouha, R. S. Kumar, and R. D. Tyagi, "Heavy metals removal from wastewater using extracellular polymeric substances produced by Cloacibacterium normanense in wastewater sludge supplemented with crude glycerol and study of extracellular polymeric substances extraction by different methods," Bioresource Technology, vol. 212, pp. 120-129, 2016.

[171] C. Bertagnolli, M. G. C. da Silva, and E. Guibal, "Chromium biosorption using the residue of alginate extraction from Sargassum filipendula," Chemical Engineering Journal, vol. 237, pp. 362-371, 2014.

[172] S. Shamim, Biosorption of Heavy Metals, IntechOpen, London, UK, 2018.

[173] M. Aryal, "A comprehensive study on the bacterial biosorption of heavy metals: materials, performances, mechanisms, and mathematical modellings," Reviews in Chemical Engineering, vol. 1-40, 2020.

[174] T. B. Ozer, I. A. Erkaya, A. U. Udoh et al., "Biosorption of $\mathrm{Cr}(\mathrm{VI})$ by free and immobilized Pediastrum boryanum biomass: equilibrium, kinetic, and thermodynamic studies," Environmental Science and Pollution Research, vol. 19, no. 7, pp. 2983-2993, 2012.

[175] S. Srivastava and I. S. Thakur, "Isolation and process parameter optimization of Aspergillus sp. for removal of chromium from tannery effluent," Bioresource Technology, vol. 97, no. 10, pp. 1167-1173, 2006.

[176] P. Malaviya and A. Singh, "Bioremediation of chromium solutions and chromium containing wastewaters," Critical Reviews in Microbiology, vol. 42, no. 4, pp. 607-633, 2016.

[177] P. A. Wani, S. Wahid, M. S. A. Khan, N. Rafi, and N. Wahid, "Investigation of the role of chromium reductase for $\mathrm{Cr}$ (VI) reduction by Pseudomonas species isolated from Cr (VI) contaminated effluent," Biotechnology Research and Innovation, vol. 3, no. 1, pp. 38-46, 2019.

[178] X. Li, M. Fan, L. Liu, J. Chang, and J. Zhang, “Treatment of high-concentration chromium-containing wastewater by sulfate-reducing bacteria acclimated with ethanol," Water Science and Technology, vol. 80, no. 12, pp. 2362-2372, 2019.

[179] S. Gupta and A. Kumar, "Removal of nickel (II) from aqueous solution by biosorption on A. barbadensis Miller waste leaves powder," Applied Water Science, vol. 9, no. 4, p. 96, 2019, https://doi.org/10.1007/s13201-019-0973-1.
[180] W. M. Ibrahim, A. F. Hassan, and Y. A. Azab, "Biosorption of toxic heavy metals from aqueous solution by Ulva lactuca activated carbon," Egyptian Journal of Basic and Applied Sciences, vol. 3, no. 3, pp. 241-249, 2016.

[181] S. K. Garg, M. Tripathi, and T. Srinath, "Strategies for chromium bioremediation of tannery effluent," in Reviews of Environmental Contamination and Toxicology Volume 217, D. Whitacre, Ed., vol. 217, Berlin, Germany, Springer, 2012.

[182] G. Ozdemir, N. Ceyhan, T. Ozturk, F. Akirmak, and T. Cosar, "Biosorption of chromium(VI), cadmium(II) and copper(II) by Pantoea sp. TEM18,” Chemical Engineering Journal, vol. 102, no. 3, pp. 249-253, 2004.

[183] A. Hansda and V. Kumar, "A comparative review towards potential of microbial cells for heavy metal removal with emphasis on biosorption and bioaccumulation," World Journal of Microbiology and Biotechnology, vol. 32, no. 10, pp. 1-14, 2016.

[184] M. Zabochnicka-Świątek and M. Krzywonos, "Potentials of biosorption and bioaccumulation processes for heavy metal removal," Polish Journal of Environmental Studies, vol. 23, no. 2, 2014.

[185] L. Velásquez and J. Dussan, "Biosorption and bioaccumulation of heavy metals on dead and living biomass of Bacillus sphaericus," Journal of Hazardous Materials, vol. 167, no. 1-3, pp. 713-716, 2009.

[186] J. Chandhuru, S. Harshitha, K. Sujitha, and D. M. Kumar, "Isolation of chromium-resistant Bacillus sp. MRKV and reduction of hexavalent chromium potassium dichromate," Journal of Academia and Industrial Research, vol. 1, no. 6, pp. 317-319, 2012.

[187] S. Chhikara, A. Hooda, L. Rana, and R. Dhankhar, "Chromium (VI) biosorption by immobilized Aspergillus Niger in continuous flow system with special reference to FTIR analysis," Journal of Environmental Biology, vol. 31, no. 5, pp. 561-566, 2010.

[188] N. T. Joutey, H. Sayel, W. Bahafid, and N. El Ghachtouli, "Mechanisms of hexavalent chromium resistance and removal by microorganisms," in Reviews of Environmental Contamination and Toxicology Volume 233, D. Whitacre, Ed., vol. 233, Berlin, Germany, Springer, 2015.

[189] V. Javanbakht, S. A. Alavi, and H. Zilouei, "Mechanisms of heavy metal removal using microorganisms as biosorbent," Water Science and Technology, vol. 69, no. 9, pp. 1775-1787, 2014.

[190] S. S. Ahluwalia and D. Goyal, "Removal of $\mathrm{Cr}(\mathrm{VI})$ from aqueous solution by fungal biomass," Engineering in Life Sciences, vol. 10, no. 5, pp. 480-485, 2010.

[191] R. Majumder, L. Sheikh, A. Naskar, M. Vineeta, M. Mukherjee, and S. Tripathy, "Depletion of $\mathrm{Cr}(\mathrm{VI})$ from aqueous solution by heat dried biomass of a newly isolated fungus Arthrinium malaysianum: a mechanistic approach," Scientific Reports, vol. 7, no. 1, pp. 11254-11315, 2017.

[192] S. Mishra and M. Doble, "Novel chromium tolerant microorganisms: isolation, characterization and their biosorption capacity," Ecotoxicology and Environmental Safety, vol. 71, no. 3, pp. 874-879, 2008.

[193] P. F. Nguema, Z. Luo, and J. Lian, “The biosorption of Cr(VI) ions by dried biomass obtained from a chromium-resistant bacterium," Frontiers of Chemical Science and Engineering, vol. 8, no. 4, pp. 454-464, 2014.

[194] R. Batool, K. Yrjälä, and S. Hasnain, "Impact of environmental stress on biochemical parameters of bacteria reducing chromium," Brazilian Journal of Microbiology, vol. 45, no. 2, pp. 573-583, 2014. 
[195] U. C. Naik, S. Srivastava, and I. S. Thakur, "Isolation and characterization of Bacillus cereus IST105 from electroplating effluent for detoxification of hexavalent chromium," Environmental Science and Pollution Research, vol. 19, no. 7, pp. 3005-3014, 2012.

[196] S. Latha, G. Vinothini, and D. Dhanasekaran, "Chromium $[\mathrm{Cr}(\mathrm{VI})]$ biosorption property of the newly isolated actinobacterial probiont Streptomyces werraensis LD22," 3 Biotech, vol. 5, no. 4, pp. 423-432, 2015.

[197] I. Zinicovscaia, A. Safonov, V. Tregubova et al., "Uptake of metals from single and multi-component systems by spirulina platensis biomass," Ecological Chemistry and Engineering $S$, vol. 23, no. 3, pp. 401-412, 2016.

[198] X. Han, Y. S. Wong, M. H. Wong, and N. F. Tam, "Biosorption and bioreduction of $\mathrm{Cr}(\mathrm{VI})$ by a microalgal isolate, Chlorella miniata," Journal of Hazardous Materials, vol. 146, no. 1-2, pp. 65-72, 2007.

[199] X. Han, Y. S. Wong, M. H. Wong, and N. F. Y. Tam, "Feasibility of using microalgal biomass cultured in domestic wastewater for the removal of chromium pollutants," Water Environment Research, vol. 80, no. 7, pp. 647-653, 2008.

[200] B. Kiran, N. Rani, and A. Kaushik, "FTIR spectroscopy and scanning electron microscopic analysis of pretreated biosorbent to observe the effect on $\mathrm{Cr}$ (VI) remediation," International Journal of Phytoremediation, vol. 18, no. 11, pp. 1067-1074, 2016.

[201] J. Wang and C. Chen, "Biosorbents for heavy metals removal and their future," Biotechnology Advances, vol. 27, no. 2, pp. 195-226, 2009. 